University of Louisville

ThinkIR: The University of Louisville's Institutional Repository

Electronic Theses and Dissertations

8-2009

\title{
Teacher attitudes toward inclusion and the impact of teacher and school variables.
}

Karla R. Stauble

University of Louisville

Follow this and additional works at: https://ir.library.louisville.edu/etd

\section{Recommended Citation}

Stauble, Karla R., "Teacher attitudes toward inclusion and the impact of teacher and school variables." (2009). Electronic Theses and Dissertations. Paper 1375.

https://doi.org/10.18297/etd/1375

This Doctoral Dissertation is brought to you for free and open access by ThinkIR: The University of Louisville's Institutional Repository. It has been accepted for inclusion in Electronic Theses and Dissertations by an authorized administrator of ThinkIR: The University of Louisville's Institutional Repository. This title appears here courtesy of the author, who has retained all other copyrights. For more information, please contact thinkir@louisville.edu. 


\title{
TEACHER ATTITUDES TOWARD INCLUSION AND THE IMPACT OF \\ TEACHER AND SCHOOL VARIABLES
}

\author{
By \\ Karla R. Stauble \\ B.S., University of Kentucky, 1981 \\ M.Ed., University of Louisville, 1996

\begin{abstract}
A Dissertation
Submitted to the Faculty of the

Graduate School of the University of Louisville

in Partial Fulfillment of the Requirements

for the Degree of
\end{abstract} \\ Doctor of Philosophy \\ Department of Teaching and Learning \\ University of Louisville \\ Louisville, Kentucky
}

August 2009 

Copyright 2009 by Karla R. Stauble

All rights reserved 


\section{TEACHER ATTITUDES TOWARD INCLUSION AND THE IMPACT OF TEACHER AND SCHOOL VARIABLES}

\section{By}

Karla R. Stauble

B.S., University of Kentucky, 1981

M.Ed., University of Louisville, 1996

A Dissertation Approved on

July 22, 2009

By the following Dissertation Committee:

Dissertation Directoy 


\section{DEDICATION}

This dissertation is dedicated to my

children Jessica, Cory and Madeline and

my husband Bob who has supported me

each time I've gone back to school

and

to my parents whose faith in me

has never wavered. 


\section{ACKNOWLEDGMENTS}

This dissertation is for my sweet son Cory who was taken from us seven years ago by a drunk driver. We had him with us for only 16 years. After finishing my Masters

degree, he was the one who encouraged me to go back to school for my Ph.D. so he could call me "Dr. Mom".

This dissertation is because of my daughters Jessica and Madeline, who were always there to urge me on when I felt I would never finish. They are the light of my life. "Thank you" is not sufficient for my husband Bob who has supported me as I have spent the majority of our married life in school. And, I cannot end without thanking my parents who continually reminded me that I can do anything I set my mind to.

I would also like to thank my dissertation committee; Dr. Karp for following through on our chance meeting at the Manual Science Fair, Dr. Alter for his encouragement, Dr. Jung for her statistical expertise, Dr. Brown for her constant enthusiasm. Special thanks go to my dissertation chair and mentor Dr. Lingo for her friendship, understanding and occasional pep talks. 


\section{ABSTRACT \\ TEACHER ATTITUDES TOWARD INCLUSION \\ AND THE IMPACT OF \\ TEACHER AND SCHOOL VARIABLES}

Karla R. Stauble

July 22,2009

This dissertation is an examination of general education teacher's attitudes toward the inclusion of students with special needs in their classroom and the variables that influence these attitudes. A theoretical framework for the examination of teacher attitudes includes the impact of efficacy, experience, training, grade level and subject area taught, and school variables. The relationship among these factors, teacher's instructional practices and student achievement are examined.

For this study, participants were recruited from three public school districts in a midwestern state. An electronic survey developed by the researcher, along with a demographic questionnaire and study preamble were sent to middle and high school general education teachers in three participating districts. A total of 233 teachers responded. Descriptive statistics were calculated. A correlational analysis between teacher attitudes and teacher and school variables along with an analysis of variance (ANOVA) was conducted.

The mean score for teacher attitudes toward inclusion was 3.79 with scores ranging from a low score of 2.96 and a high of 4.94 out of a possible score of 6.00 . An analysis of the data revealed a negative correlation between teacher attitude and grade 
level taught meaning that the higher the grade level, the more negative the teacher attitude toward inclusion. A significant difference in teacher attitude toward inclusion by subject area taught was found. Participants who teach mathematics reported significantly lower attitudes toward inclusion than those who taught language arts and social studies. A further analysis revealed that almost $25 \%$ of the participants had no training what-so-ever in special education strategies, $48.5 \%$ of the teachers surveyed strongly agreed or moderately agreed that inclusion is a desirable practice and $44.7 \%$ of the teachers strongly or moderately agreed that everyone benefits from inclusive practices.

When examining the findings of this study in light of the literature, teacher training has been identified as a primary contributor to teacher attitudes. Suggestions for providing general education teachers with the needed training are made as well as directions for future research. 
TABLE OF CONTENTS

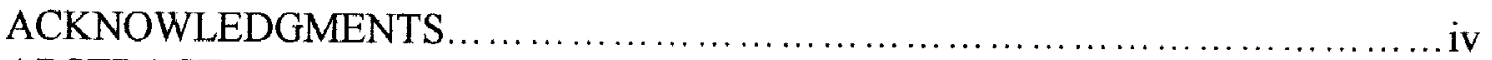

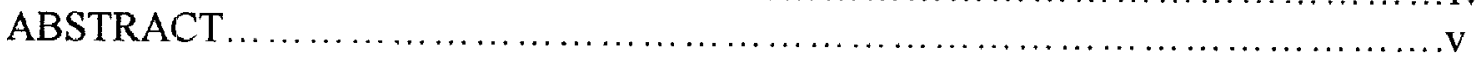

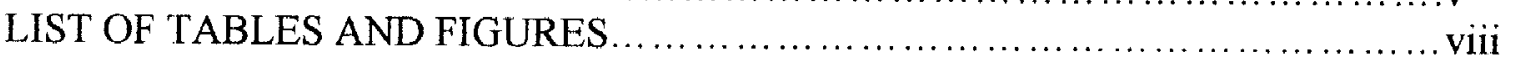

CHAPTER

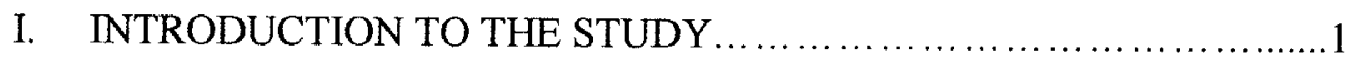

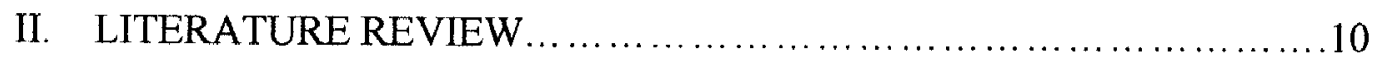

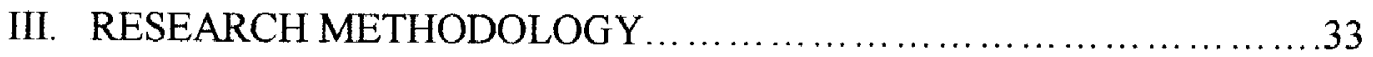

IV. DATA ANALYSIS ........................................... 44

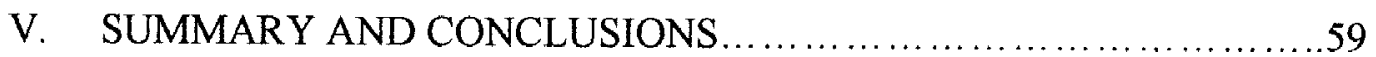

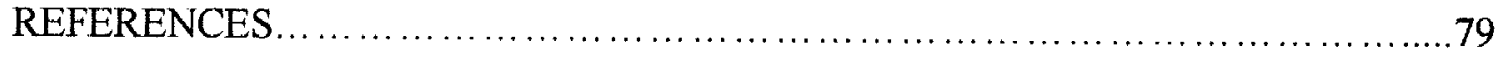

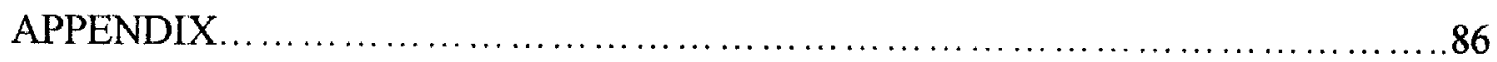

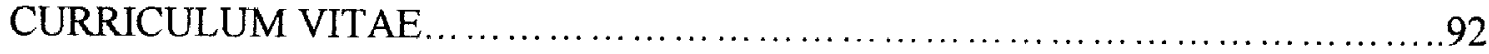




\section{LIST OF TABLES AND FIGURES}

FIGURES

1. Conceptual Framework for Teacher Attitudes.

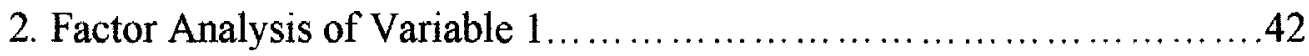

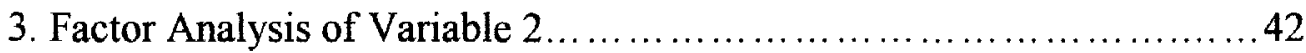

4. Factor Analysis of Variable 3 ..................................... 43

\section{TABLES}

1. Participating School Districts..................................... 34

2. Pilot Study: Instrument Factor Analysis..........................41

3. Demographic Data for Study Participants.............................48

4. Mean Numbers by Survey Question..............................550

5. Intercorrelations between Teacher Attitudes and Teacher and School variables............................................ 52

6. Analysis of Variance for Teacher and School Variables.................55

7. Summary of Research Findings.............................. 54

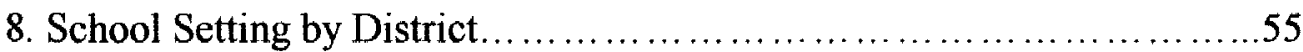




\section{CHAPTER ONE \\ INTRODUCTION TO THE STUDY}

This study examined general education teachers' (GET) attitudes toward inclusionary practices and students with special needs (Ssp). The study also examined correlations between teacher and school variables and teachers' attitudes toward inclusion. Surveys were sent electronically to middle and high school GETs from a large Midwest urban public school system and two surrounding districts from a 14 member cooperative of suburban and rural public school systems. The survey included a demographic questionnaire and the Teacher Attitudes of Inclusive Practices Scale (TATIP) which was developed by the researcher. The data was analyzed using SPSS, a statistical analysis program, using both a correlational analysis and an analysis of variance (ANOVA). From the analyzed data, ideas for addressing teacher attitudes through pre-service and inservice training were discussed.

Currently, more than six million students in the United States receive some form of special education services (NEA Today, nd). This is compared to 4.7 million ten years earlier. According to the $27^{\text {th }}$ Annual Report to Congress (2005) for 2003, this represents $9.1 \%$ of all children ages 6 through 21 . This figure has risen from $8.1 \%$ in 1993 . This report revealed that almost $50 \%$ of Ssp spend more than $79 \%$ of the instructional day in a regular education setting which is defined as full inclusion. This figure is up from $43.4 \%$ 
for 1993. In this midwestern state, the number of Ssp receiving services in a regular classroom for more than $79 \%$ of the instructional day rose from $50 \%$ in 1999 to $59 \%$ in 2003. Many of these students are placed with GETs who are expected to make the necessary modifications with little training or support from special education teachers who are spread thin. With more and more Ssp being placed in general education settings, the attitudes of GETs becomes very important to student performance. Teachers' attitudes may influence their willingness to make accommodations, their persistence with difficult to teach students, and their preconceived beliefs about a student's ability to learn.

With the enactment of Public Law 94-142 in 1973, students with disabilities were guaranteed access to a free appropriate public education. This law guarantees that Ssp receive services in the least restrictive environment appropriate for their educational needs. The required adherence to the least restrictive environment has moved increasingly larger numbers of students into the regular classroom setting where they are taught by GETs who may hold both positive and negative attitudes toward their inclusion.

The development of an accepting classroom environment or state of mind toward inclusion may be easily influenced by that teacher's attitude toward inclusion. When discussing the inclusion of Ssp, Voltz, Brazil, and Ford (2001) stressed that inclusion is a teaching philosophy or state of mind where students are actively engaged with their nondisabled peers, not a physical location in a classroom or school building. They believe that inclusion guides how teachers respond to student differences to promote academic success.

Many educators believe that the inclusion of Ssp in the regular education program benefits all students as they work together in the classroom (Scruggs \& Mastropieri, 
1996; Stoler, 1992). Despite this, research on the effectiveness of inclusive practices yield mixed reviews. Stoler reported that some GETs are concerned that students in the general education program do not receive the attention they need when Ssp are in the classroom. Other studies show that many Ssp do make academic progress in the general education classroom (Madden \& Slavin, 1983). In a report compiled by the National Center for Educational Restructuring and Inclusion (1995), Ssp in inclusive settings were found to have improved grades, higher standardized test scores, increased on-task behavior and more motivation to learn. However, there are gaps in the research. The majority of studies addressing teacher attitude have focused on elementary teachers. Few studies have addressed the attitudes toward inclusion of middle and high school teachers and the impact the subject area taught may have on teacher attitude. High stakes testing has also added pressure on teachers to push all students to higher levels of achievement. This is in light of new regulations requiring that Ssp be included in all accountability testing. No research was found that addressed the impact of this stress on teacher attitudes toward inclusion.

Minke, Bear, Deemer, and Griffin (1996) stated that for many teachers, educating Ssp is evaluated as one would conduct a cost analysis. Teachers must balance the additional time spent making adaptations for their Ssp against the benefit accrued for the majority of students (Minke et al.). Minke et al. stated that most GETs prefer a resource or pull-out arrangement for addressing the educational needs of Ssp in the absence of additional resources. In a research synthesis conducted by Scruggs and Mastropieri (1996), 30.3\% of teachers felt that including Ssp in the general education classroom could be harmful to the performance of students without disabilities. 
As large numbers of students with disabilities enter the general education classroom, they bring a new set of challenges for the GET. These challenges include addressing a wide range of academic needs, behavior issues, a lack of necessary resources and training in special education strategies. GETs are required to invest more time to plan for modifications and secure resources to teach Ssp and may spend $90 \%$ more time instructing these students than general education students (Johnson \& Fullwood, 2006). Often, inclusion places students in classrooms with teachers who lack the training needed to meet their educational needs. In a study by the U.S. Office of Special Education Programs (March 2005), schools reported that less than $41 \%$ of teachers felt capable of improving the academic performance of a student with special needs. Less than $46 \%$ were prepared to use accommodations in their classrooms and only $39 \%$ were prepared to teach students with special needs the general education curriculum. Only $37 \%$ of GET reported being comfortable using a positive behavior modification system with their special education students.

In earlier research on teacher preparedness, Buell, Hallam, Gamel-McCormick, and Scheer (1999) identified a lack of trained personnel capable of teaching students with special needs in an inclusive setting as the primary barrier to successful inclusion. Silva and Morgado (2004) stated that a teacher's attitude toward inclusion is influenced by their training and experience. They found that the more training a teacher receives in special education, the more positive their attitude toward inclusion. This is also supported by Brownell and Pajares (1999) who found that teachers who had taken special education courses or received inservice training used more effective instructional strategies and had 
greater job satisfaction than those teachers with no training in special education. This training prepares teachers to make the accommodations necessary for Ssp.

General educators' attitudes may impact several classroom factors including class discipline, peer acceptance of Ssp, and the academic success of all students. The attitudes GETs hold toward Ssp may have an impact on the overall classroom climate (Stoler, 1992). In general, studies show that GETs are often less tolerant of Ssp behavior than special education teachers (SET) and may respond in a more punitive manner (Johnson \& Fullwood, 2006). Hughes, Cavell, and Willson (2001) reported that students' perceptions of teacher-student relationships influence their acceptance of their peers with disabilities. The researchers found that when teachers respond in a positive and caring manner to students with behavior concerns, their peers are often found to be more accepting. Brownell and Pajares (1999) stated that GETs who lack confidence in their ability to teach Ssp may rely on control and negative sanctions to deal with students and blame Ssp academic problems on a lack of motivation. Gibson and Dembo (1984) found that teachers with a greater confidence in their ability to teach Ssp were more persistent in providing students with additional help.

A number of variables may impact a GET's perception of inclusion and Ssp. Besides the amount of training in special education, teachers' attitude toward inclusion may also be impacted by the severity of the disabilities of the students in their class, the grade level taught, and years of experience. Scruggs and Mastropieri's (1996) research synthesis evaluated 28 studies addressing teacher attitudes toward inclusive practices and found that while the majority of teachers supported the concept of inclusion, variance in responses were noted based on the severity of the disability. The teachers' attitudes 
toward inclusion became less favorable as the severity of the disability increased. In a study by Chiang (1999) of secondary teachers, the teachers held the assumption that the Ssp who were in inclusive classrooms were not college bound.

\section{Problem Statement}

Research has shown that teacher attitudes toward inclusion shape their expectations for students, influence the instructional strategies used and ultimately student achievement. Over 30 years of research has documented the impact that teachers' expectations may have on student learning (Hughes, Gleason, \& Zhang, 2005; Kagan, 1992). The goal of inclusion of Ssp is to provide them access to challenging curriculum, access to teachers with the necessary content knowledge, and an opportunity to interact with their non-disabled peers. The attitude of the teachers may determine whether or not these goals are achieved. The studies discussed earlier describe the influence of teacher and school variables on attitudes toward inclusion and Ssp. This study evaluated the attitudes of middle and high school GETs and the relationship between attitude scores and the following variables: teacher experience, teacher training (whether the teacher had completed any coursework in special education or held dual certification in special education), grade level and subject area taught, school setting (rural, suburban, or urban), and school performance level as measured by No Child Left Behind (NCLB).

The research questions that guided the study were:

1) What are middle and high school general education teachers' attitudes toward the inclusion of students with special needs in the general education classroom as measured by the TATIP? 
2) Is there a correlation between the teacher attitude scores and selected school and teacher variables (school setting, school achievement level as measured by No Child Left Behind, grade and subject taught, teacher training including dual certification in special education)?

\section{Professional Significance of the study}

Studying teachers' attitudes toward inclusion and their Ssp are vital if students are receiving instruction in the general education program. Attitudes may impact the instructional strategies and discipline practices used by the teachers (Kagan, 1992; Kuklinski \& Weinstein, 2001). Therefore, these attitudes may influence the academic and social success of Ssp. This study focused on several under-researched variables. As the majority of studies in the literature focus on elementary teachers' attitudes, this study focused on middle and high school teachers. This study also examined the impact of content area taught on the attitude toward inclusion of middle and high school general education teachers. The impact of content area on teacher attitudes toward inclusion has received little attention in the literature.

This study also contributes to the planning of pre-service education programs. Wilcox-Herzog and Ward (2004) stated that teachers' attitudes are formed during their own learning experiences and these experiences filter later learning in teacher education programs and early teaching experiences. The researchers explained that changing these attitudes is difficult and often requires some dissonance-producing experience such as planned internships, and varied meaningful educational experiences. College coursework and quality inservice training have also been found to impact teacher attitudes (Siegel \& 
Jausovec, 1994). Understanding how teachers' attitudes are formed and ultimately how they may be changed could lead to increased academic achievement for Ssp. This information could be beneficial in planning teacher education programs and designing activities which encourage pre-service teachers to examine their attitudes about the inclusion of Ssp.

\section{Overview of Methodology}

This study evaluated correlations between teacher attitudes and teacher/school variables. Permission to conduct the study was obtained from the districts involved, after approval by the university IRB. Survey instruments were sent electronically to every middle and high school general education teacher in the cooperating schools from the target districts. The survey instrument included a demographic questionnaire and a teacher attitude scale. The demographic questionnaire addressed the teacher's age, years in teaching, certifications held, number of students in their class identified with special needs, and the subject they currently teach. It also included information on the school's performance level as determined by NCLB. The TATIP scale was designed by the researcher to measure teacher attitudes toward inclusion and their perceptions of the Ssp in their classrooms. The survey was developed from several existing instruments, piloted with three graduate education classes and modified based on a factor analysis. The instrument is scored on a six-point Likert scale. Some questions were minimally adapted from the original instrument to reflect current terminology. The completed surveys were evaluated using SPSS for correlations between TATIP scores and individual teacher and school variables. The research methodology is discussed in more detail in Chapter three. 


\section{Key Terms}

Attitudes toward Ssp: the GETs expectations of behavior, academic performance, and motivation to learn; appropriateness of placement in inclusive setting. Attitudes toward inclusion: the GETs' understanding of their roles and responsibilities in making adaptations for Ssp, their personal beliefs about inclusion, and confidence in their training.

Students with Special Needs (Ssp): for the purpose of this study, this will refer to students identified with a learning disability, emotional/behavior disability, and mild mental disability

\section{Limitations}

There are several limiting factors which may affect the generalizability of this study. As with any attitude scale or self report survey, the accuracy of the data collected is dependent upon the honesty of the respondents. The return rate on the survey was impacted by the support of the study by each school district or principal and their willingness to encourage teacher participation. Despite the directions in the preamble to the survey, a number of ineligible teachers completed the survey. These surveys were removed from the sample. 
CHAPTER TWO

\section{LITERATURE REVIEW}

As more and more students with special needs (Ssp) are included in the general education program, the attitudes of general education teachers (GET) toward inclusion have become very important (Siegel, 1992). Early in the inclusive movement, general education and special education teachers held different views on the benefit of mainstreaming Ssp into the general education classroom. While the special education classroom was seen as a preferred placement for Ssp by many GETs, other educators contended that students were not given access to the general education curriculum or opportunities to socialize with peers in the general education program as required by law. Larrivee and Cook (1979) stated that placement in special education classrooms was at best ineffective and at worst, damaged a student's academic progress.

While researchers and special education teachers supported the inclusive movement, the "buy-in" of GETs was seen as essential. The literature shows that positive teacher attitudes and support for inclusion are key to the success of inclusive schools (National Center on Educational Restructuring and Inclusion, 1995; Smith, 2000). Smith asserted that the acceptance of Ssp by their peers, will only come about with changes in attitude of teachers and that these attitudes are complicated to understand as they are tied to prior experience as well as teacher and school variables. 
When discussing teacher attitudes toward inclusion, it is important to examine the evolution of the inclusive movement and the various roles of GETs. In 1968, Dunn described the existing system for educating handicapped children as obsolete and unjustifiable. This was supported by special education teachers (SET) who, in the early 1970 's, expressed a need to educate mildly handicapped students in the general education classroom (Bender, 1985; Bender, Vail, \& Scott, 1995; Gickling and Theobald, 1975). With the passage of the Education of all Handicapped Children Act (PL 94-142) in 1973 by the Federal Government, students with special needs (Ssp) were ensured the right to a free and appropriate public education in the least restrictive environment appropriate for their disability. Many Ssp though, continued to receive special education services in separate classrooms for all or part of their school day. The belief by SETs that students with mild disabilities should be served in a general education setting was not necessarily shared by GETs. So, the majority of Ssp continued to be served in resource and selfcontained classrooms segregated from their peers.

A renewed push toward mainstreaming Ssp emerged in the 1980's with the regular education initiative (REI). At this point in time, the emphasis in special education shifted from the individual student to the program and a move away from segregated classrooms (Kavale \& Forness, 2000). This initiative called for the collaboration between regular and special education teachers to provide services for Ssp in the regular education classroom (McLeskey \& Pacchiano, 1994). The goal behind this push for inclusion was the creation of learning communities where all students' needs were met (Kavale \& Forness). While initially supported by the federal government, REI came under closer scrutiny as concern over a lack of support from GET began to emerge (Bender, 1985; 
Bender, Vail, \& Scott, 1995). Other strategies have been introduced directed toward the goal of keeping students in the regular education program.

Response to Intervention (RtI) is an alternate approach to the deficit model in the early detection of specific learning disabilities and the implementation of intervention strategies (Martinez, Nellis, \& Prendergast, 2006). RtI requires the GET to implement research based instructional strategies often developed in special education classrooms and then consistently collect formative assessment data on their at-risk students. This model typically consists of three tiers of intervention. Tier one usually involves implementing class-wide evidence-based interventions. Tier two interventions are more intense and implemented short-term. Tier three involves more intense, long-term strategies implemented one-on-one or in small groups ("The Response", 2006). This requires that the GET possess a working knowledge of a variety of intervention strategies and data collection methods often associated with special education, to successfully implement RtI. The appropriate implementation is dependent on the GET being trained to work with students with disabilities.

Over the past decade, the Education of all Handicapped Children Act has undergone several changes including being renamed the Individuals with Disabilities Act (IDEA) in 1990. In 1997 and 2004 changes were enacted which mandated further consideration for providing access to the general education curriculum. As this push to include Ssp in the general education program gained momentum, more research has focused on the attitudes of GETs, how these attitudes evolve, and how they impact student achievement. These factors are the basis for the conceptual framework of this study. 


\section{Conceptual Framework}

From the work of Bandura $(1986,1993)$, Pajares $(1992,1996)$ and others, a conceptual framework for this study was developed. The research in this review will examine teacher attitudes toward inclusion of students with special needs in the general education classroom. Literature examining the link between teacher attitude, the instructional practices implemented and the impact on student achievement will be reviewed. Connections in the literature between teachers' attitudes and their instructional practices will also be examined.

The degree to which GETs are capable of modifying instruction and making accommodations to ensure access to the general education curriculum for Ssp are vital to their success. Studies show that the beliefs and attitudes of GETs shape the instructional practices they use and ultimately impact the academic achievement of Ssp (Kagan, 1992; Vaughn \& Schumm, 1996). It is the understanding of researchers that teacher attitudes are linked to instructional practices and student achievement that drives this study.

As illustrated in Figure 1, a reciprocal relationship exists between teacher attitudes toward inclusion, instructional practices and student performance. For example, when a general education teacher experiences success using a particular strategy with a Ssp, their attitude toward inclusion may become more positive as a result of the student's success (Larrivee \& Cook, 1979; Lohrmann \& Bambara, 2006).

It is well documented that the instructional strategies used by classroom teachers have a direct impact on student achievement. Researchers have studied the relationship between teacher behaviors and student learning for three decades. Munro (1999) stated that a teacher's effectiveness has a profound impact on learning. Through his research, 
Munro found that when effective teaching strategies were implemented, low achieving students made greater academic gains. So, it could be said that teachers who have a positive attitude toward inclusion may use more effective instructional strategies which could positively impact student achievement.

A number of studies have been identified that show teachers' attitudes toward inclusion may be influenced by a number of variables such as years in teaching, grade level and subject area taught, experience teaching students with special needs, and training in special education strategies (Brownell \& Pajares, 1999; Larrivee \& Cook, 1979; Stella, Forlin, \& Lan, 2007).

Figure 1. Conceptual Framework for Teacher Attitudes

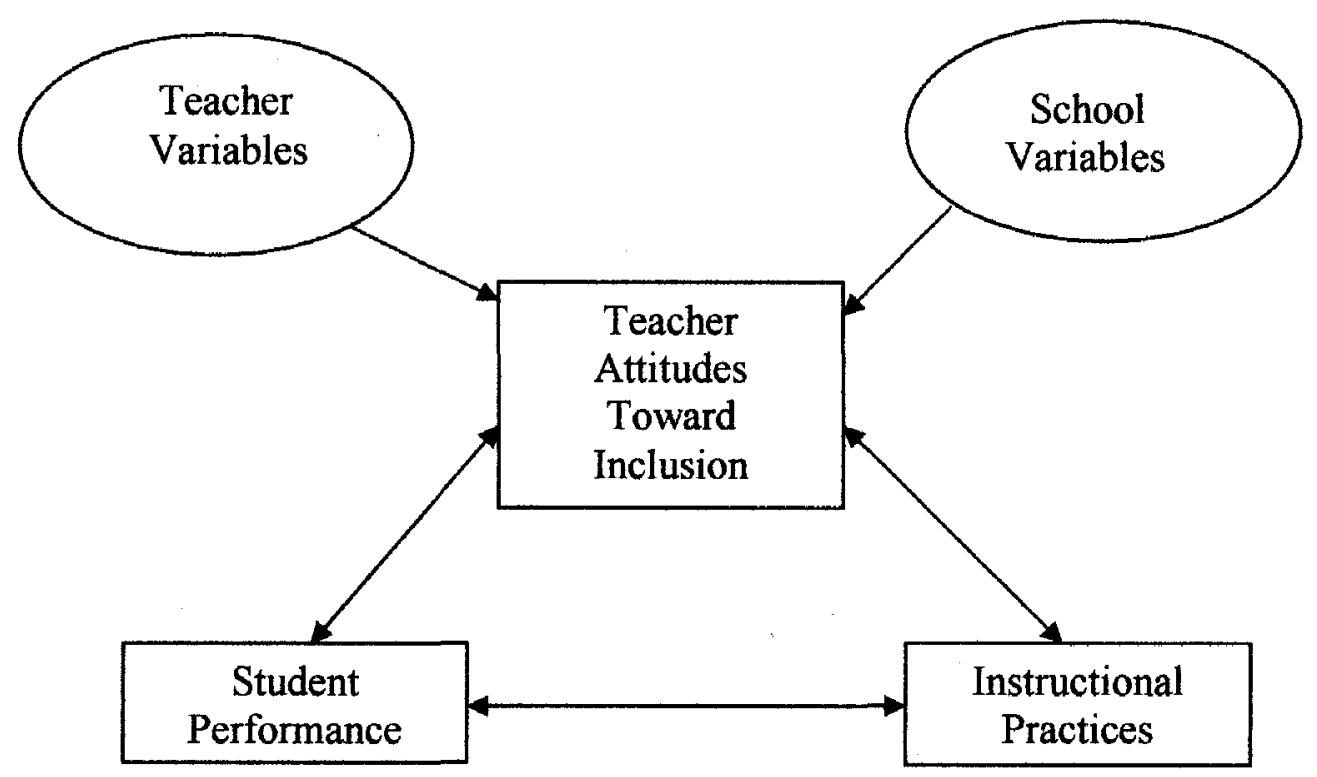

To better understand teacher attitudes toward inclusion and Ssp, it is important to examine the nature of attitudes, the variables that influence teacher attitudes including 
efficacy, and how they might be changed through pre-service and in-service training. These topics are addressed in this review.

\section{Review of the Literature}

To compile information for this review of the literature, an internet search of the following databases was conducted: Academic Search Premier, Educational Resources Information Center (ERIC), Psych INFO, Professional Development Collection, and TOPIC search. The key terms used for the search included: teacher attitude, teacher efficacy, disabilities, inclusion, special education, and specific content areas. Initially, 137 articles were identified that addresses teacher attitudes and special education. Forty four of the identified articles were research studies with the remaining 93 articles addressing the theoretical basis for this study. After review, 62 of the 137 articles were eliminated as they failed to meet the following criteria:

1. Studies were included if they addressed the impact of school variables, teacher variables, or student variables on general education teachers' attitudes, beliefs or efficacy and the inclusion of students with special needs in their classroom.

2. International studies were included if the inclusive practices of the country closely resembled those in the United States.

3. Studies of teacher attitudes toward the inclusion of students with specific learning disabilities (SLD), emotional and behavior disorders (EBD), and mild mental disabilities (MMD) were included. Those addressing other disabilities were eliminated. 
4. Studies of attitudes of school principals, special education teachers, other support staff or students were not included.

\section{Key Terms}

Defining teacher attitudes has been a challenge for researchers. This is complicated because throughout the literature, the terms attitude, belief, values and perceptions are used interchangeably. The American Heritage Dictionary (1985) defines attitude as a state of mind or feeling regarding some matter. Attitudes may also be described as deeply held personal truths which may be formed by life experiences, cultural influences or by chance and influence how teachers learn from their experiences (Pajares, 1992). Attitudes make up the affective component of teaching (Nespor, 1987). For this study, attitudes and beliefs will be defined as the personal truths and biases, unconscious assumptions, and feelings teachers hold about the inclusion of students with special needs in the general education program.

For the purpose of this study, general education teachers (GET) will include middle and high school regular program teachers in language arts, mathematics, science, and social studies. Inclusion refers to the placement of students with special needs (Ssp) in the general education program for at least $80 \%$ of the school day. Students with special needs will include those identified as having a specific learning disability (SLD), an emotional/behavioral disability (EBD), or a mild mental disability (MMD).

Introduction to the Issue: Attitudes Toward Inclusion

Scruggs and Mastropieri (1996), in their review of studies between 1972 and 1987 found that when teachers were questioned about the broad concept of inclusion of Ssp in 
the general education program, $65 \%$ were supportive but when the concept was described in more detail including the responsibility for adapting curriculum, only $40.5 \%$ of GETs supported inclusion. While the studies in this review spanned 15 years of research, Scruggs and Mastropieri found no relationship between the teachers' responses and the dates the studies were conducted. Six years after the latest study included in this review, Criswell, Anderson, Slate and Jones (1993) found that after completing a questionnaire on their attitudes toward inclusion, GETs somewhat disagreed with the concept of inclusion. The researchers also reported that only $21 \%$ of the GETs surveyed felt it was their responsibility to make modifications for the Ssp in their classes.

Villa, Thousand, Meyers, and Nevin (1996) also examined the attitudes of GETs toward the full inclusion of Ssp in the general education classroom. Seventy-eight percent of the GETs reported a sense of shared responsibility with SETs for the education of all students, a view that GETs and SETs are equal partners, and that inclusion does not negatively impact student achievement. The researchers attributed this high acceptance rate to the above average experience working in a collaborative setting of the participating teachers. They theorized that this experience produced more positive attitudes toward inclusion. It has been shown that the more training and positive experiences a GET has working with Ssp, the more willing they are to make the accommodations needed to insure student success. 
Variables that Impact Attitude

\section{Training.}

Many teachers report a negative attitude toward inclusion because they feel they lack the training needed to meet the needs of Ssp (Koutrouba, Vamvakari \& Steliou, 2006; Siegel \& Jausovec, 1994). The quality of preparation teachers receive either in their pre-service coursework or inservice training may influence teachers' attitudes toward inclusion and Ssp. The research consistently shows that teachers who have received training in teaching students with special needs showed more positive attitudes toward inclusion (Avramidis \& Kalyva, 2007; Brownell \& Pajares, 1999; Stoler, 1992).

Pre-service teachers enter college education programs with firmly held attitudes or beliefs based on their own personal experiences as students and most graduate with the same belief system about teaching that they held before beginning their program (Kagan, 1992). For some, their beliefs and biases become more deeply embedded during their preservice experiences. Kagan suggested that these beliefs may be more easily shaped or changed by actual field experiences than by theory taught in the classroom. In most programs, pre-service teachers are never forced to examine their personal beliefs. Pajares (1996) asserted that the longer a belief is held, the more difficult it may be to change. To change these deeply held attitudes, pre-service teachers should be pushed to analyze the source of their beliefs and the impact these beliefs have on their teaching (Pajares).

Jung (2007), when comparing the attitude toward inclusion of pre-service teachers and student teachers, found that pre-service teachers showed more positive attitudes. Also in the same study, student teachers who had participated in quality field experiences working with Ssp reported more positive attitudes than those who had not. The researcher 
suggested that the negative attitude expressed by student teachers was a reflection of the lack of confidence in their teaching ability. Jung felt that while many education programs report that inclusive practices are infused throughout their methods courses, they lack intensive focused attention on inclusion. Experience working with Ssp in an inclusive setting helps GETs develop their skills in meeting the needs of their students and in turn, improves their attitude toward inclusion (Villa, Thousand, Meyers, \& Nevin, 1996).

Brownell and Pajares (1999) examined the impact of pre-service and inservice training in special education, on teacher efficacy. Surveys were completed by 128 randomly selected second grade GETs. The data revealed that the greater the number of special education courses taken by GETs, the more positive their attitude toward inclusive education. Similar results were found for the level of education. Researchers found that teachers with a master's degree held more positive attitudes toward inclusion than those with bachelor's degrees and that the masters level teachers were more tolerant of students with behavior problems (Johnson \& Fullwood, 2006; Parasuram, 2006).

The same findings were reported by Brownell and Pajares (1999) for the amount and quality of inservice training teachers receive. The researchers found that teachers were most interested in training that addressed 1) needs of Ssp, 2) adaptations in curriculum and instruction, and 3) behavior management strategies. Brownell and Pajares noted that inservice training and coursework in special education have been found to encourage collaboration between GETs and SETs and thereby improving GETs attitudes toward inclusion. Teachers who have received quality training merging general and special education programs reported using more effective instructional strategies, being open to teaming, collaboration, and differentiating instruction and experiencing greater 
job satisfaction (Avramidis \& Kalyva, 2007; Brownell \& Pajares; Villa, Thousand, Meyers, \& Nevin, 1996).

\section{Years of experience.}

The majority of studies reviewed, agree that years of experience and experience working with Ssp results in more positive attitudes toward inclusion (Avramidis \& Kalyva, 2007; Jung, 2007; Lohrmann \& Bambara, 2006; Tschannen-Moran \& Hoy, 2007). Villa, Thousand, Meyers and Nevin (1996) reported that experience teaching Ssp was one of the most influential factors in shaping GET attitudes toward inclusion and that experience teaching Ssp improved the GET's confidence and instruction and thus their attitude toward inclusion.

Parasuram (2006) found that teachers reported the most positive attitudes toward inclusion after 1 to 5 years experience and 25 or more years of experience. The positive attitudes of the more novice group were attributed to an increased exposure to technology and changing attitudes while the more positive attitudes of the experienced group were due to their extensive classroom experience. The most negative attitudes were reported by teachers with between 15 to 20 years of experience.

The relationship between teacher beliefs and student characteristics was the focus of Soodak, Podell and Lehman's (1998) study. Teacher efficacy, which may influence beliefs, was found to impact attitudes toward inclusion. Teachers with a strong sense of teaching efficacy who use inclusive strategies in their classroom have positive attitudes toward inclusion. But, teachers with a poor sense of teaching efficacy who also use inclusive strategies, report negative attitudes toward inclusion. When looking at disability 
classifications, GETs were the least accepting of students identified as LD, EBD and mentally disabled as compared to those with physical disabilities. They became frustrated when these students failed to make the progress seen in resource classrooms. The researchers found that GETs receptivity to students with LD decreased as years of teaching experience increased. They suggested several theories for this change in attitude one being the frustration felt by experienced teachers who feel a strong sense of responsibility in teaching Ssp. Another theory is that newer teachers have been trained in inclusive practices in their pre-service education program. Tschannen-Moran and Hoy (2007) found though that novice teachers reported lower self efficacy than career teachers and that these teachers either develop better instructional strategies which lead to a higher sense of efficacy or they leave teaching; the option chosen by $25 \%$ of new teachers in the United States.

Larrivee and Cook (1979) after surveying 941 GETs, found that along with experience, a GET's perceived success in teaching Ssp, had a significant impact on teacher attitudes toward mainstreaming. The researchers asserted that experience teaching Ssp improves the GET's confidence and instruction and thus their attitude toward inclusion. Teachers who have confidence in their ability to meet the educational needs of Ssp, are more willing to try multiple instructional strategies to ensure student success and are more likely to persevere with difficult students rather than taking a custodial approach to their education (Brownell \& Pajares, 1999; Bender \& Ukeje, 1989; Gibson \& Dembo, 1984). Lohrmann and Bambara (2006) found that teachers reported more positive attitudes toward inclusion after experiencing success teaching Ssp and an increase in motivation. They referred to this change in attitude as a transformational experience. The 
researchers explained that when teachers are given time to try a variety of instructional strategies with Ssp, their attitudes may shift toward an acceptance of inclusion. Providing pre-service teachers with opportunities to observe and work in quality collaborative placements may provide this transformational experience. Encouraging school administrators to provide time and support for inservice training and the development of collaborative relationships between teachers may also help to shape GET's attitude toward inclusion.

\section{Subject area and grade taught.}

The research on the impact of grade level and subject area taught on teacher attitudes toward inclusion is limited. For this review, five studies addressing grade level, five addressing subject area, and two studies addressing the relationship between these variables were identified. Overall, the studies reveal that more positive attitudes toward inclusion are reported by elementary teachers with the most negative attitudes reported by middle and high school teachers.

Research on the impact of grade level on teacher attitudes toward inclusion found that the higher the grade level taught, the less positive the teacher's attitudes with those of middle school teachers often being the lowest (Bender, Vail, \& Scott, 1995; Larrivee \& Cook, 1979). Similar results were reported by Lopes, Monteiro, Sil, Rutherford and Quinn (2004) almost ten years later, when they found that GETs in grades 5-9 had the lowest scores for personal efficacy in teaching Ssp. This group of teachers also strongly agreed that the inclusion of Ssp interfered with general education students' learning and most were concerned with their ability to meet the educational needs of these students. 
DeSimone and Parmar (2006) concluded that middle school teachers do not have the opportunity to develop one-on-one relationships with their Ssp or with their special education colleagues. They pointed out that elementary teachers spend their entire day in one setting with their students and have the opportunity to bond more closely while middle and high school teachers typically teach one content area, are more assessment driven, and have less contact time with their students. Middle school teachers are also under increasing pressure to cover larger amounts of content material often with shorter class periods to their students. DeSimone and Parmar felt that the majority of the GETs in their study did not have a clear understanding of learning disabilities and appropriate instructional strategies and that only $29 \%$ of the middle school teachers felt that middle schools were successfully implementing inclusion.

These findings were supported by Smith (2000) who theorized that less positive attitudes toward inclusion among middle and high school teachers may be due to the large amount of material that these teachers are responsible for teaching. The complexity in managing the schedules of Ssp who might need additional support both inside and out of the general education classroom in middle and high school was also cited as contributing to the negative attitudes of middle and high school teachers toward inclusion (Villa, Thousand, Meyers, Nevin, 1996).

While few studies were found that address the impact of content area taught, those reviewed reported similar results. Ross, Cousins and Gadalla (1996) found that a teacher's sense of efficacy varied from class to class depending on the student characteristics and subject area they were teaching supporting the belief that efficacy is situation specific. This means that a teacher's attitude toward inclusion may vary 
somewhat from class to class especially if they are preparing lessons in different subject areas. This may compound the need for training in instructional strategies specific to each subject area taught. A teacher may also report a positive attitude toward inclusion one year and less positive the next.

Ellins and Porter (2005) also examined the differences in teacher attitudes toward inclusion by subject taught. Teacher attitudes toward inclusion were measured using a survey that included open-ended questions and teacher interviews. They found that while not statistically significant, the mean score for attitude toward inclusion by subject area was at the positive end of the neutral range of the banded scores. When analyzing the means by subject area, science scores were the only subject scores in the negative end of the neutral band. The lowest mean attitude scores were recorded for science, math, and language arts. Also, $50 \%$ or more of the teachers in all subject areas reported a positive attitude when the scores were reduced to three bands (positive, neutral, negative) with the exception of science which continued to report negative attitudes. The researchers found that scientific vocabulary and complex concepts were blamed for the difficulty in including Ssp in science classrooms. They stated that the science teachers in their study paid little attention to the needs of their Ssp possibly explaining why these students reported the least academic gain in science. Math, science and English teachers also mentioned the external pressures brought on by district, state and national testing as influencing their attitude toward inclusion. Ellins and Porter theorized that teachers who have received more content-specific training often have more negative attitudes toward inclusion. 
The relationship between teacher attitudes toward inclusion and content area was also found to be influenced by student disability category, specifically, those with EBD. Johnson and Fullwood (2006) found that teachers in the related arts and vocational studies held the most negative attitudes toward inclusion when looking at disturbing behaviors. The most positive attitude toward inclusion of students with EBD was reported by science and mathematics teachers. The researchers suggested that the Ssp in these core academic courses are often sent to resource classrooms taking the burden of dealing with problem behaviors off the GETs.

DeSimone and Parmar (2006) studied the attitudes toward inclusion of middle school teachers looking only at those teaching mathematics. The researchers found that only $42 \%$ of the mathematics teachers felt that the general education program was the most appropriate placement for Ssp and 44\% felt that these students were better prepared in mathematics. Avramidis, Bayliss, and Burden (2000) looked specifically at the attitudes toward inclusion of pre-service teachers. Those with a concentration in science held the most negative attitudes toward inclusion of the pre-service teachers in this study. The pre-service teachers expressed concern over their student's ability to master the science content.

The results of the studies on the impact of subject area taught on teacher attitudes toward inclusion draws attention to the need for more extensive training in inclusive instructional strategies for teachers in specific content area education programs. 
School variables: School performance level, setting.

Little research exists in the literature addressing the impact of a school's achievement level as determined by some nationally administered assessment (ex. No Child Left Behind) or the impact of school setting (rural, suburban, or urban). For each of these variables, only two studies were found.

Garrison (2004) found a number of differences in teacher behaviors when looking at low, average, and high achieving schools. The teachers in lower achieving schools controlled the flow of instruction, relied more heavily on in-class seat work, and had difficulty with classroom management. In contrast, the teachers in higher achieving schools utilized a more student-centered approach, paced their lessons around student progress, and incorporated projects and group work into their teaching. These teachers spent far less instructional time addressing student behavior. Brookover, Schweitzer, Schneider, Beady, Flood, \& Wisenbaker (1978) found that teachers from high achieving schools spent a proportionately larger amount of time on instruction and were more invested in the success of all their students including their Ssp.

When attitude was correlated with school setting, the data revealed that teachers in rural schools felt less successful in teaching Ssp (Larrivee \& Cook, 1979). Bulgren et al. (2002) found that urban teachers had the least confidence in the availability of needed resources to teach, reported the lowest level of involvement in the IEP process, and made no modifications to their teaching plans based on the IEP. Urban teachers were also less likely to use technology with their Ssp. Suburban teachers were the most likely group to refer students for placement, were the most involved in the IEP process, and had the most confidence in the services provided. They were also more willing to make modifications 
to assessments. Rural teachers were found to be the least likely to refer students for special education services seeing the services as ineffective and while the most aware of their students' IEPs, like urban teachers, they reported making no changes to their teaching plans based on these IEPs. Surprisingly, $27 \%$ of rural school teachers, $36 \%$ of suburban teachers and $52 \%$ of urban teachers reported not wanting to participate in any training focused on instructional strategies for Ssp.

Knoblauch and Hoy (2008) looked at the relationship between efficacy, which contributes to attitude, and school setting. Because efficacy has been described as situation specific, school setting may have an impact on efficacy and teacher attitudes. The researchers state that rural and urban schools often face more challenges than suburban schools. Teachers from urban settings often deal with large class sizes, a lack of educational and community resources, and students from low socioeconomic households. Rural teachers face a lack of resources due to very small schools but do benefit from a stronger sense of community and family support. Surprisingly, Tschannen-Moran and Hoy (2007) in their study, found that the school setting had little impact on efficacy contrary to their belief that the more challenging urban school environment would result in lower teacher efficacy.

Importance of this Study

Role of Attitude in Teacher Behavior and Instructional Practices

Much research has been devoted to understanding how teacher attitudes ultimately impact instructional practices. In a study by Woolfolk, Rosoff, and Hoy (1990), data show that a teacher's attitude toward their students and of their teaching is a 
strong predictor of their instructional practices. The researchers have also shown that for learning to occur, teachers must feel competent in their ability to teach Ssp. Studies also show that a teacher's behavior in the classroom may have a profound effect on the success of their students (Vaughn \& Schumm, 1996). Liljequist and Renk (2007) stated that teachers are the most important adult in a child's life, second only to their parents/primary caregivers and have the ability to influence a child's self-esteem, work habits, values and self-control. So it may be implied that the attitudes teachers hold toward inclusion and Ssp may impact the way GETs interact with and instruct their students. The impact a teacher's actions have on a student, which are shaped by attitudes and beliefs, may have a profound impact on the student's academic success.

When looking at the relationship between attitudes and instructional practices, it is important to understand that attitudes or beliefs toward teaching are quite different from knowledge of teaching (Nespor, 1987; Pajares, 1992). While knowledge represents the cognitive process of teaching, attitudes are based on perceptions and judgments about students. Pajares pointed out that one's knowledge of a domain may be quite different from their feelings about the same domain. Attitudes are also more influential than knowledge in determining how teachers approach instruction and are a stronger predictor of classroom behavior (Pajares, 1996). And, unlike knowledge which accumulates and changes with new information, attitudes are not easily changed by education or discussion and, no group consensus is required to validate the belief (Nespor; Pajares, 1996). Pajares asserted that an individual's attitude toward some factor may be a stronger predictor of future classroom behaviors and successes than any other factors including the individual's education level, skill or prior experiences. 
A teacher's attitude toward instruction influences how they view their responsibilities and shape their instructional practice (Nespor, 1987). Kolb and Jussim (1994) described the impact of self-fulfilling prophecies and perceptual biases on instruction. Self-fulfilling prophecies are described as when a teacher's negative expectations based on their attitude toward a student or group of students are projected onto that student. These negative attitudes may eventually lead to student failure. Perceptual biases occur when teachers evaluate their students based on their attitudes or beliefs rather than their actual performance. Students with disability labels are often evaluated less favorably than their non-disabled peers. These influences on student performance are rooted in teacher attitudes and illustrate the need to address these attitudes directly through teacher training.

Cook, Tankersley, Cook, and Landrum (2000) investigated the impact of a disability label on teachers' attitude toward their Ssp. The researchers explained that teachers' attitude toward their students may be separated into four categories; attachment, concern, indifference, and rejection as described by Silberman (1969). Using Silberman's classification system, they explain that teachers feel attachment for students who are self motivated and high achievers who require little of the teacher's time. Teachers exhibit concern for students who experience academic difficulties and are still self-motivated, spending more time in direct instruction with these students. These students struggle, but their teachers continue to feel they can make a difference. Teachers often feel indifference toward students who are quiet and tend to avoid interactions with their teachers. Finally, rejection is felt for students who exhibit academic failure and behavior 
problems. While these students receive much attention from their teachers, most is related to behavior concerns and not academics.

When applying Silberman's classification system in their study, Cook, Tankersley, Cook, and Landrum (2000) hypothesized that GETs would be more likely to rate their Ssp in the concern and rejection categories. As predicted, Ssp were significantly underrepresented in the attachment category, and significantly overrepresented in the concern and rejection categories. Almost $30 \%$ of the Ssp nominated by their teachers were placed in the rejection category.

Obiakor (1999) pointed out that teacher attitudes directly impact teachers' expectations of their students and often a child's performance reflects those expectations. When teachers hold low expectations for students, the classroom climate they create may encourage underachievement and lead to self-fulfilling prophecies (Kolb \& Jussim, 1994; Safran, Safran, \& Orlansky, 1982).

Role of Attitude in Student Performance

As discussed earlier, teachers' attitude toward inclusion and Ssp may impact their instructional practices and ultimately, these attitudes may impact student achievement. Teachers may hold unconscious assumptions about their students and the educational potential they possess (Kagan, 1992). These assumptions or perceptual biases have been found to influence how they evaluate their students (Kolb \& Jussim, 1994). Students with handicaps or disability labels are often evaluated less favorably than their non-disabled peers. Obiakor (1999) pointed out that teacher attitudes directly impact teachers' expectations of their students and often a child's performance reflects those expectations. 
When teachers hold low expectations for students, the classroom climate they create may encourage underachievement (Kolb and Jussim). Safran, Safran, and Orlansky (1982) stated that teachers' attitudes toward their students yield expectations which may ultimately lead to self-fulfilling prophecies.

Silva and Morgado (2004) investigated the factors thought to contribute to the academic success of Ssp in Portugal where these students are educated full time in the general education classroom. Seventy-six teachers were asked to identify the factors they felt contributed to the academic success of Ssp in the general education program. Thirty seven percent of the teachers listed teaching approach, $21.3 \%$ mentioned school climate, $20.5 \%$ mentioned curriculum design, $11 \%$ listed student characteristics, and $8.8 \%$ listed out-of-school context. When asked about factors that may contribute to students' academic failure, the teachers listed factors that were beyond their control. Little importance was placed on the role of curriculum design or teaching approach. Silva and Morgado concluded that GETs instructional practices and willingness to implement substantive instructional modifications are key to student academic success. The researchers also stressed the role of collaboration between general education and special education staff as well as professional development to address teacher attitudes and instructional strategies.

As the research has shown, teacher attitudes can influence perceptions of students, classroom instruction and student achievement. The attitudes of GETs toward inclusion may have a profound impact on the success of students with special needs. A discussion of the impact of teacher attitudes toward inclusion is especially important when discussing the academic achievement of Ssp who seem to be more vulnerable to changes 
in instructional style, curricular demands and teacher expectations than general education students (King, 2003). Teacher attitudes toward inclusion and their sense of efficacy are shaped by the variables discussed in this review. A teacher's attitude toward inclusion may influence the instructional strategies they use and their perseverance in working with Ssp. It has also been shown that quality training and opportunities to experience success working with Ssp has a positive impact on teacher attitudes. An understanding of the relationship between these variables and attitudes toward inclusion can be used to guide teacher training practices and promote the acceptance of Ssp into the general education program. Ultimately, by improving teacher attitudes toward inclusion, Ssp will experience greater academic success.

\section{Current Study}

This dissertation study examined middle and high school general education teachers' attitudes toward inclusion and students with special needs and the variables that have been found to impact those attitudes. The variables examined in this study include pre-service and inservice training as well as dual certification in special education, years of experience, grade level and subjects taught, school setting (urban, suburban, or rural), and the school's performance as measured by No Child Left Behind. 


\section{CHAPTER 3}

\section{METHODOLOGY}

This chapter outlines the methodology used to conduct this study of general education teachers' (GET) attitudes toward students with special needs (Ssp) and the variables that impact these attitudes. Data were collected using an electronic survey distributed through the participating school districts e-mail system. As described by Watson (1998), survey research is the most appropriate method for collecting information on attitudes when direct observation is not an option. A quantitative analysis was used to investigate the possible correlation between teacher attitudes toward inclusion and teacher and school variables thought to influence those attitudes. The following research questions were addressed in this study:

1) What are general education teachers' attitudes toward the inclusion of students with special needs in the general education classroom as measured by the TATIP? 2) What is the relationship between these attitude scores and selected school and teacher variables (school setting, school performance level as measured by No Child Left Behind, grade and subject taught, pre-service and inservice training as well as dual certification in special education instructional strategies)? 


\section{Context for the Study}

This study was conducted in a large midwestern public school system and a 14 member educational cooperative of surrounding suburban and rural public school systems. The large public school system (district B) was selected for the diversity in the student population. This predominantly urban and suburban district is the $28^{\text {th }}$ largest district in the country with 89 elementary, 24 middle and 22 high schools (excluding special schools). Districts within the educational cooperative were selected based on a collaborative relationship with the university. The 14 district cooperative includes 51 elementary, 21 middle and 17 high schools. Table 1 provides a profile of the three districts that agreed to participate in the study. Data collection began in the fall of 2008 and continued for two months. Data collection continued until an acceptable response rate was reached.

\section{Table 1}

Participating School Districts

\begin{tabular}{llccccc}
\hline $\begin{array}{l}\text { School } \\
\text { District }\end{array}$ & $\begin{array}{l}\text { Total } \\
\text { Students }\end{array}$ & $\begin{array}{c}\text { Total } \\
\text { \# of Ssp } \\
\text { (MMD, SLD, EBD) }\end{array}$ & $\begin{array}{c}\text { \# High } \\
\text { Schools }\end{array}$ & $\begin{array}{c}\text { \# Middle } \\
\text { Schools }\end{array}$ & $\begin{array}{c}\text { \# Elem } \\
\text { Schools }\end{array}$ & $\begin{array}{r}\text { Total \# } \\
\text { Teachers }\end{array}$ \\
\hline District A & 1550 & $302(72)$ & 1 & 1 & 2 & 85 \\
District B & 92,056 & $13,877(4721)$ & 22 & 25 & 88 & 5570 \\
District C & 6,070 & $1,026(559)$ & 1 & 2 & 5 & 339 \\
\hline
\end{tabular}

\section{Research Participants}

The participants in this study included GETs employed in the school districts recruited for this study. The study targeted middle and high school teachers as they are 
underrepresented in the research. Teachers were sent a preamble explaining the purpose of the study, requirements for participation, and clarifying that participation was optional (see Appendix A).

\section{Data Collection Instrument}

The GETs in the study were asked to complete a demographic data sheet (see Appendix B). The demographic questionnaire included participants' gender, age, education/training in teaching Ssp, certifications held, subject area taught and years of teaching experience. School demographic information included school setting (urban, suburban or rural) and school performance as defined by No Child Left Behind (meets annual measurable objectives, showing progress, or identified for improvement). Each participant then completed the Teacher Attitude Toward Inclusive Practices (TATIP) survey (see Appendix C). The development of the TATIP is described in detail in the following section of this chapter. A six-point Likert scale for teacher responses was selected to avoid neutral responses and this "forced choice" method is used to ensure that participants respond either more positively or negatively to an item (Semmel, Abernathy, Butera, \& Lesar, 1991). The TATIP was created from 8 existing instruments found in the literature and contains 16 items selected through a series of factor analytic methods. A similar method of instrument development was used by Brownell and Pajares (1999), DeSimone and Parmar (2006), and Wilcox-Herzog and Ward (2004) when they combined categories from several existing observation instruments to create the instruments for their studies. When negatively worded items were selected for the 
TATIP, they were reverse coded using SPSS so that high scores reflected positive attitudes and low scores reflected more negative attitudes.

From an extensive review of the literature on teacher attitudes toward Ssp, a number of published instruments were identified. Each instrument was reviewed based on their alignment with the focus of this study which was to measure GETs' attitudes toward inclusion, timeliness of the content, and question format. Eight instruments were selected for further consideration based on their evaluation of GETs' attitudes toward inclusion. The selected instruments demonstrated reliability as defined by alpha reliability coefficient, Cronbach's alpha coefficient and internal consistency. These measured the extent to which the items in an instrument measure a single construct. George and Mallery (2003) offered the following guidelines for evaluating alpha coefficients: alpha greater than 0.9 is excellent, an alpha between 0.89 and 0.8 is good, and an alpha between 0.79 and 0.7 is considered acceptable.

Questions for the TATIP were drawn from the Teachers' Perceptions of Problem Students (Lopes, Monteiro, Sil, Rutherford, \& Quinn, 2004) with an internal consistency of .73, the Survey of Teacher Attitudes (Minke, Bear, Deemer, and Griffin, 1996) with a Cronbach alpha coefficient of .77, the Attitudes Toward Mainstreaming Scale (Antonak \& Livneh, 1988) with an alpha reliability coefficient of .88, School Environment Project questionnaire (Cook, Semmel, \& Gerber, 1999) with a Cronbach alpha coefficient of .82 , the Regular Education Initiative Teacher Survey (Semmel, Abernathy, Butera, \& Lesar, 1991) with a Cronbach alpha coefficient of .87, the Heterogeneous Education Teacher Survey (Villa, Thousand, Meyers, \& Nevin, 1996) with a Cronbach alpha coefficient of .84 , the Attitudes of School Personnel questionnaire (Criswell, Anderson, Sate, \& Jones, 
1993) with a Cronbach alpha coefficient of .89, and the Differentiated Teaching Survey (Soodak, Podell, \& Lehman, 1998) with a Cronbach alpha coefficient of .79. From these, 43 items were selected which addressed teacher attitudes toward inclusion, educational needs of Ssp, and teacher attitudes toward their preparation to teach Ssp. The items in the initial instrument were placed in the following categories: needs of special education students, attitudes toward special education/inclusion, and teacher training/preparedness. The pilot instrument was distributed to three experts in the field whose expertise was in research design, teacher efficacy research, and special education, for a professional evaluation of validity. Recommended changes were made to the instrument as deemed appropriate by the researcher and experts. These included eliminating ambiguous questions, updating terminology, and separating questions with multiple components into separate questions.

The pilot instrument was administered to three graduate-level education classes at the university with a total of 54 students participating. Incomplete surveys were eliminated and the responses from the remaining 42 surveys were entered into SPSS for a factor analysis. Of the pilot group there were 33 females, 4 males, and 5 undeclared gender. Twenty six respondents were elementary teachers, 8 taught in middle school and 8 in high school. Twenty three of the teachers had five or less years of experience, 10 teachers had 6 to 10 years, and 9 had 11 or more years of experience. One respondent had no teaching experience.

The items in the pilot instrument were assessed based on an analysis of the responses from the pilot study, input from consulting experts and a series of factor analytic methods using SPSS. Five questions (numbers $23,38-41$ ) were eliminated based 
on their focus on personal experience versus general attitudes. As the focus of the study is on the academic impact of inclusion, questions about the emotional impact of inclusion were eliminated (numbers $8,11,12$, and 18). At this time, a factor analysis was run on the remaining 34 items to identify common variables and eliminate questions that did not align with these. Three variables were identified with Eigenvalues above one as illustrated in the Scree plot (see Figure 2). Eigenvalues are a measure of the variance in data that can be explained by the factor with which it has been associated. Additional questions were then eliminated when they failed to align with one of the three identified variables. This accounted for an explained cumulative variance of $61.25 \%$.

A second factor analysis was run on each of the three variables yielding two factors each as identified in the Scree plots (see figure 3 and 4). This second analysis was run using a Varimax rotation technique. Variable A with factor loadings between 0.81 and 0.517 , consisted of factor one (questions $1,2,31$ ) and factor two (questions $5,7,21$, 24, 26, 43) which assess teacher attitudes. Examples of items in variable A include "To teach students with $\mathrm{LD}$ or MMD is too hard a task to be handled by general education teachers" and "Special education students should be served primarily through resource classes rather than in general education classes." Variable B with factor loadings between 0.89 and 0.527 also consisted of factor one (questions 16 and 27) and factor two (questions 3, 4, 10, 17, and 28) and assessed Teachers' Attitudes about the Impact of Inclusion on Instruction. Some sample questions for this variable include "The needs of the majority of children with disabilities can be met in the general classroom" and "It is possible to adapt curriculum for a student with LD or MMD and/or disruptive student." Variable C, the Impact of Inclusion on School Climate, failed to produce a sufficiently 
high reliability coefficient and was deleted. The mean response and standard deviation for each of the retained items are listed in Table 2 by factor $\mathrm{A}$ and $\mathrm{B}$ and descending factor loading. The final instrument consisted of 16 items. The reliability of each variable was calculated. A Cronbach's Alpha reliability coefficient of .86 was obtained for the nine items in variable A, Teacher Attitudes. The Cronbach Alpha reliability coefficient was .72 for the seven items in variable B, Teachers' Attitudes about the Impact of Inclusion on Instruction. Although the communality scores for items $3(.53)$ and $4(.56)$ were relatively lower than the other items, after a close examination of their relative contribution to factor B and the percent of variance explained, these items were retained in the final analysis. These items addressed the responsibility of the GET to modify the curriculum for their Ssp.

\section{Procedures}

Once IRB approval was obtained, the office of Accountability, Research and Planning of district B and the Director of Special Education of each cooperative district were contacted for permission to conduct the study. Once permission was granted, the survey preamble with a link to the survey and demographic questionnaire were distributed to each districts' contact person, on LiveText (http://college.livetext.com), an online Accreditation Management System for managing web-based information which was chosen for its compatability with SPSS. The contact person was asked to include a statement encouraging teacher participation. Respondents were not asked for their name and were only identified by their district. Electronic reminders were sent every 2 weeks until 233 responses were received. 


\section{Data Analysis}

The data collected on the demographic questionnaire and the attitude scale were then imported into SPSS for analysis. Negatively worded items were reverse coded (questions $1,3,4,5,7,9$ ). Descriptive statistics were calculated for the overall attitude score and teacher and school variables such as years of experience, pre-service and inservice training including dual certification in special education, grade level and subject area taught, school setting and school performance level.

A correlational analysis was run between TATIP scores and the teacher and school variables. The correlation coefficient was used to measure the strength and direction of any relationship identified between the teachers' attitude score and teacher and school variables. The correlation coefficient was evaluated for statistical significance. An analysis of variance (ANOVA) was conducted to pinpoint where variances existed. An ANOVA was selected as the data meets the design requirements which include comparing two or more means for the independent variable (participation in pre-service training, participation in inservice training, and whether or not the teacher is dual certified in special education) and the dependent variable (teacher attitude toward inclusion) is measured on an interval or ratio scale of measurement. The findings were then compared with those of prior studies found in the literature. An analysis of power for the study was conducted. The power was found using a Case I: One-Tail Significance Test. 
Table 2

Pilot Study: Instrument Factor Analysis

\begin{tabular}{|c|c|c|c|c|c|c|c|c|}
\hline Factor & Item & & & & & h2 & Mean & SD \\
\hline \multirow[t]{7}{*}{$\mathrm{AF} 1$} & Teacher Attitudes & AF1 & AF2 & $\mathrm{BF} 1$ & $\mathrm{BF} 2$ & & & \\
\hline & $\begin{array}{l}\text { Having a special education student in my classroom is } \\
\text { disruptive }\end{array}$ & .815 & & & & .74 & 4.40 & 1.55 \\
\hline & $\begin{array}{l}\text { Students with "normal curricula" and students with } \\
\text { "alternative curricula" can be taught in the same } \\
\text { classroom. }\end{array}$ & .714 & & & & .68 & 4.26 & 1.42 \\
\hline & $\begin{array}{l}\text { The general education teacher is required to make } \\
\text { appropriate modifications in their teaching whenever a } \\
\text { special education student's learning deficits influence } \\
\text { their classroom success. }\end{array}$ & .704 & & & & .82 & 5.21 & .81 \\
\hline & $\begin{array}{l}\text { General educators and special educators are coequal } \\
\text { partners who share responsibility for the education of } \\
\text { all children in their school. }\end{array}$ & .641 & & & & .62 & 5.29 & 1.26 \\
\hline & $\begin{array}{l}\text { General classroom teachers have the instructional skills } \\
\text { to teach both students with mild handicaps and general } \\
\text { education students. }\end{array}$ & .583 & & & & .52 & 4.20 & 1.54 \\
\hline & $\begin{array}{l}\text { Special education students should be served primarily } \\
\text { through resource classes rather than in general } \\
\text { education classes. }\end{array}$ & .517 & & & & .79 & 4.31 & 1.24 \\
\hline \multirow[t]{4}{*}{$\overline{\mathrm{AF} 2}$} & Attitudes and Service Delivery & & & & & & & . \\
\hline & $\begin{array}{l}\text { To teach students with LD or MMD is too hard a task } \\
\text { to be handled by general education teachers. }\end{array}$ & & .81 & & & .78 & 4.52 & 1.42 \\
\hline & $\begin{array}{l}\text { To teach disruptive students is too hard a task to be } \\
\text { handled by general education teachers. }\end{array}$ & & .696 & & & .69 & 3.93 & 1.47 \\
\hline & $\begin{array}{l}\text { General classroom teachers cannot meet the academic } \\
\text { needs of students with mild handicaps currently in their } \\
\text { classrooms. }\end{array}$ & & .68 & & & .81 & 4.29 & 1.60 \\
\hline \multirow[t]{3}{*}{$\overline{\mathrm{BF} 1}$} & Impact on Instruction & & & & & & & \\
\hline & $\begin{array}{l}\text { Everyone benefits from heterogeneous educational } \\
\text { practices. }\end{array}$ & & & .858 & & .76 & 4.16 & 1.53 \\
\hline & $\begin{array}{l}\text { The needs of the majority of children with disabilities } \\
\text { can be met in the general classroom. }\end{array}$ & & & .741 & & .66 & 3.76 & 1.53 \\
\hline \multirow[t]{6}{*}{$\mathrm{BF} 2$} & Modifications & & & & & & & \\
\hline & $\begin{array}{l}\text { In general, mainstreaming is a desirable educational } \\
\text { practice }\end{array}$ & & & & .893 & .82 & 4.6 & 1.37 \\
\hline & $\begin{array}{l}\text { Achievement levels of students with mild disabilities } \\
\text { would increase if they were placed full time in the } \\
\text { general classroom. }\end{array}$ & & & & .816 & .67 & 4.12 & 1.43 \\
\hline & $\begin{array}{l}\text { The social and emotional needs of children with mild } \\
\text { disabilities are better met in resource classrooms than } \\
\text { general education classrooms. }\end{array}$ & & & & .769 & .72 & 3.86 & 1.10 \\
\hline & $\begin{array}{l}\text { Educational modifications that work with students with } \\
\text { learning disabilities are different from those that work } \\
\text { with average students. }\end{array}$ & & & & .563 & .35 & 3.72 & 1.50 \\
\hline & $\begin{array}{l}\text { It is possible to adapt curriculum for a student with LD } \\
\text { or MMD and/or disruptive student. }\end{array}$ & & & & .527 & .40 & 4,81 & 1.44 \\
\hline
\end{tabular}

Factor loadings for variables $A$ and $B$ 
Figure 2: Factor Analysis of TATIP Survey

\section{Scree Plot}

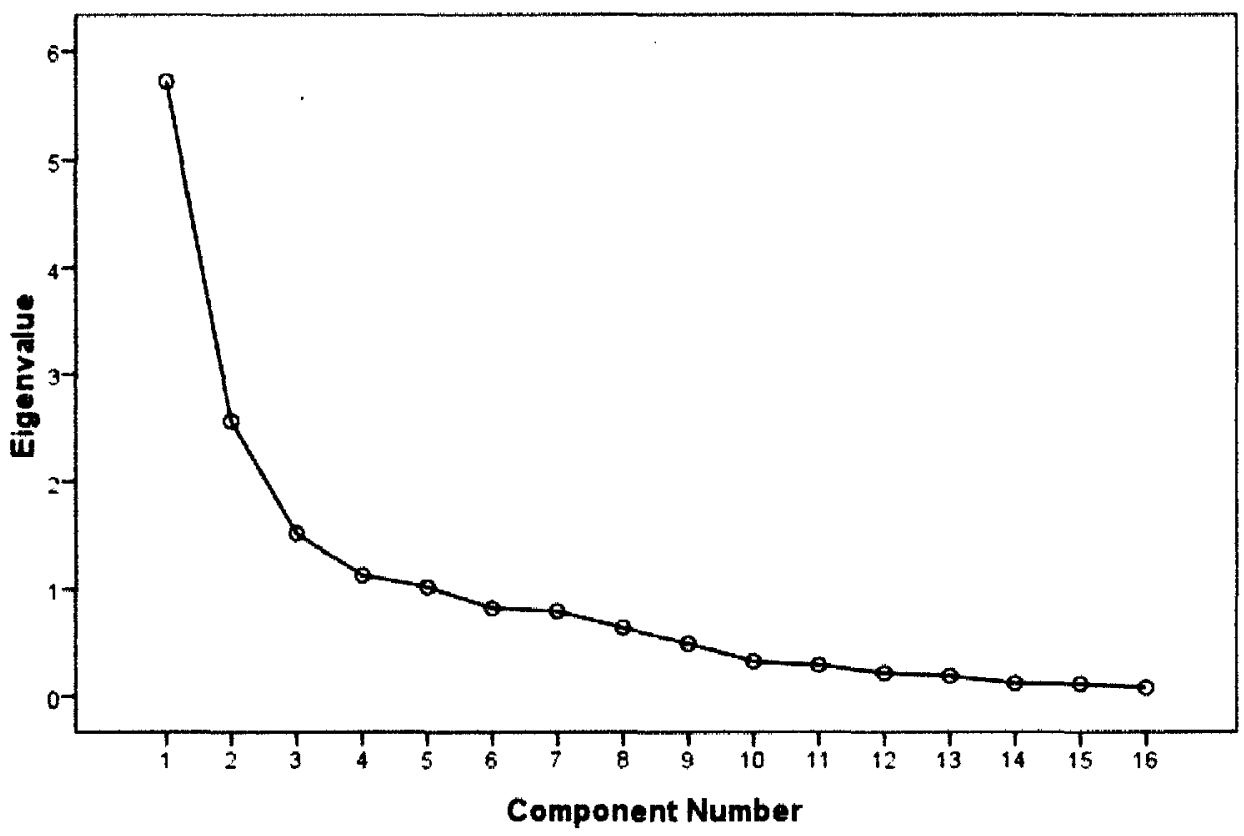

Figure 3: Factor Analysis of Factor A: General Attitudes

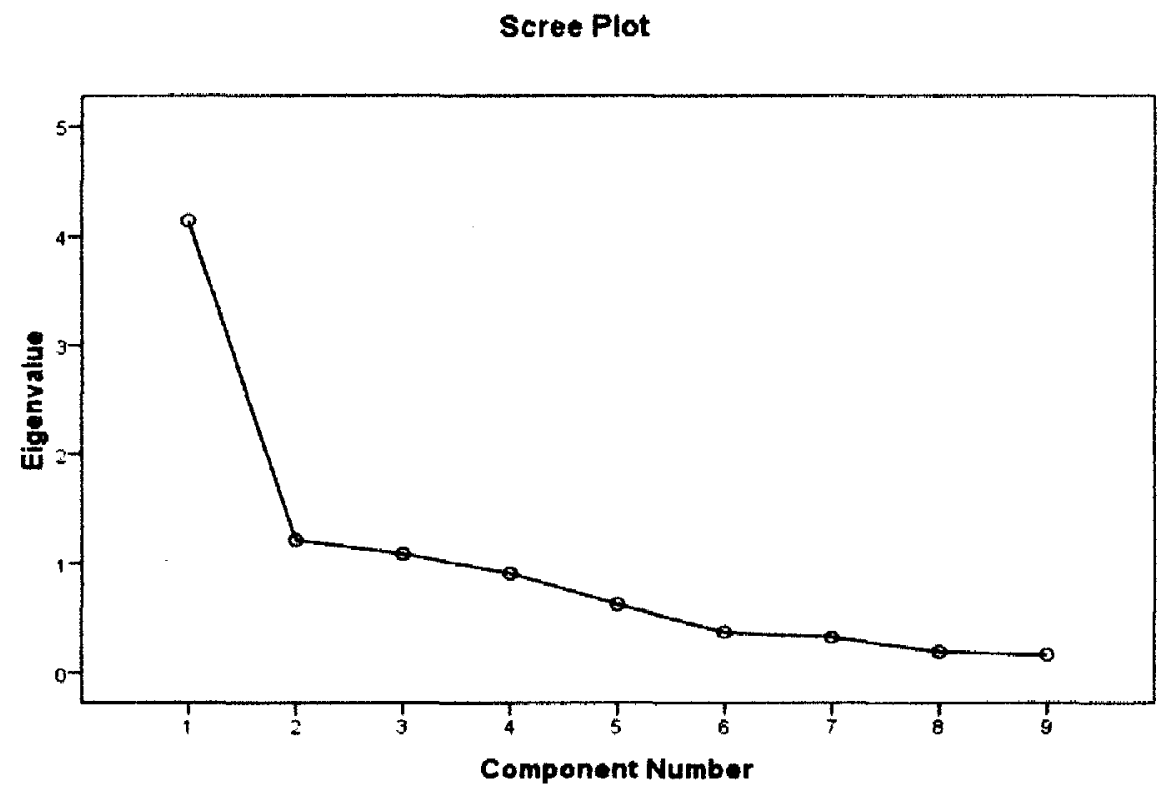


Figure 4: Factor Analysis of Factor B: Teachers' Attitudes about the Impact of Inclusion on Instruction

Scree Plot

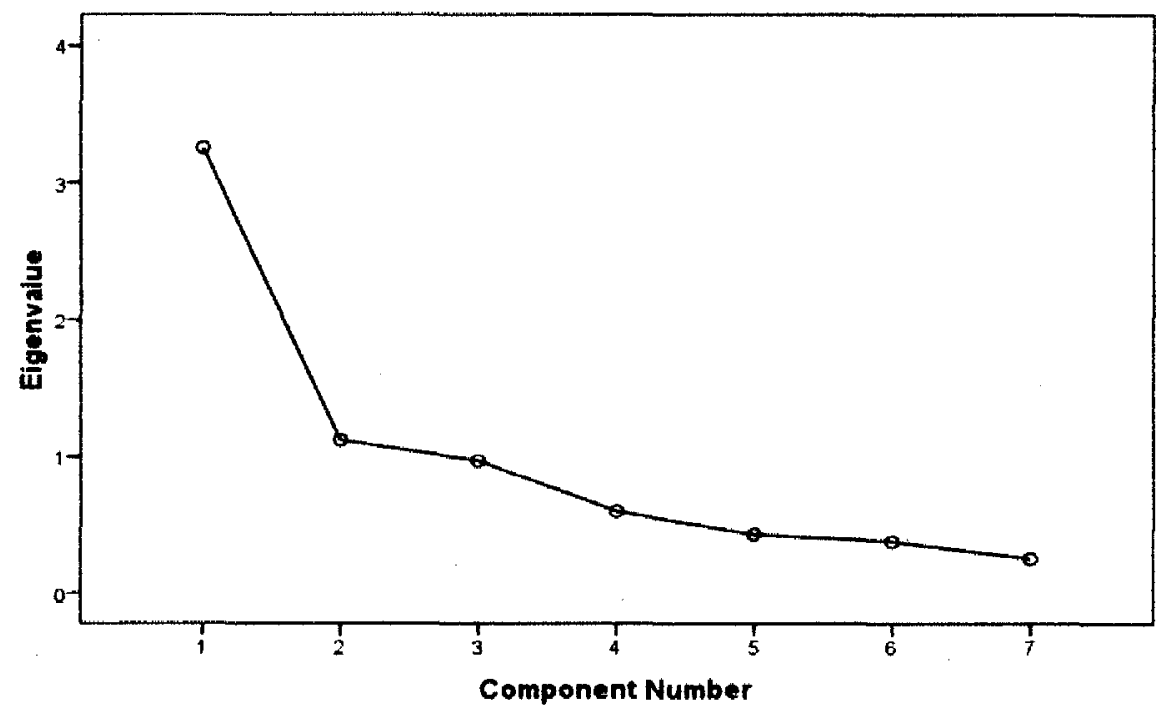




\section{CHAPTER 4}

\section{RESULTS}

Research has shown that teacher attitudes may impact the instructional strategies implemented in their classrooms, the expectations they hold for their students and ultimately, student achievement. General education teachers' (GET) attitudes toward inclusion may impact the access students with special needs (Ssp) have to the general education curriculum and the accommodations made for these students. This correlational study will explore GETs' attitudes toward the practice of inclusion and the Ssp served in their classrooms, and examine the correlation between teacher/school variables and teachers' attitudes towards inclusion.

This study was conducted in a midwestern state with a population of over 4 million people, 174 public school districts, and 1249 public schools. The state department of education serves over 671,000 students with more than 109,000 receiving special education services. The department employs over 43,700 public school teachers. The state includes urban, suburban and rural school districts.

\section{Procedures}

To begin this study, school districts were recruited from a thirteen district educational cooperative that works closely with the university. The districts in this 
cooperative are predominately from suburban and rural areas of the state. The largest district in the state was also recruited for the study and serves urban and suburban communities. An endorsement of the study was obtained from the Director of Special Education for the set of cooperative districts. A description and purpose of the study, a copy of the survey instrument, and a request for permission to conduct the study were sent to the Directors of Special Education in each district Where required by the district, an application to conduct research was submitted. From the districts contacted, three agreed to participate in the study.

The survey questions were set up using LiveText, an online Accreditation Management System for managing web-based information. LiveText was selected for its easy to use format and accessibility by the study participants. A preamble with the electronic link to the survey was distributed to a contact person in districts $\mathrm{A}$, and $\mathrm{C}$ on December 9,2008 with the instruction to distribute to the middle and high school general education teachers in their district. In district $B$, the survey link with a request to participate, was sent to each middle and high school principal on December 16, 2008 as directed by the district's research office. Principals were asked by email to distribute the survey to their general education teachers. A reminder was then sent to each district and district B principals on January 22, 2009. A second and third reminder were sent through email on February 10, 2009 and February 17, 2009 to each district contact and district B principals along with a request for verification that the surveys had been distributed and the number of teachers receiving the survey. As recommended by Watson (1998), four contacts with each participating district or principal were made. Due to school holiday breaks and snow days, the data collection phase of the study exceeded the 7-10 day 
period recommended for e-mail surveys (Watson). Using the responses from district contacts and principals, the response rate for the study was calculated. The total number of responses received $(\mathrm{N}=223)$ was divided by the number of teachers receiving the electronic survey (617). This yielded a response rate of $36 \%$. Thirty percent is considered an average response rate for an online survey (Instructional Assessment Resources, 2007). This will be addressed further in chapter 5 .

\section{Results}

The following data are based on the responses to the Teacher Attitudes Toward Inclusive Practices (TATIP) and demographic questionnaire which were collected electronically. The TATIP consisted of 16 questions utilizing a 6 point forced choice Likert scale $(1=$ strongly disagree, $2=$ moderately disagree, $3=$ slightly disagree, $4=$ slightly agree, $5=$ moderately agree, and $6=$ strongly agree). The survey was designed to measure the attitudes of general education teachers toward the inclusion of students with special needs in the general education program. The demographic questionnaire collected information on the teachers' age, gender, certification, the grade and subject area they teach, and whether they have received pre-service and inservice training as well as dual certification in special education. Information was also collected on the school setting (urban, suburban, or rural) and the school performance level. At the close of the data collection period, all responses were downloaded from LiveText to an Excel spreadsheet and then to a Statistical Package for the Social Sciences (SPSS) database.

A review of the survey data revealed a number of responses from teachers who did not meet the qualifications for participation. The qualifications for participation 
required that a teacher teach in the general education program in a middle or high school. Some school principals and smaller districts distributed the survey to all of their teachers rather than just those described in the preamble. Because of this, 33 responses completed by elementary and special education teachers were thus eliminated from the dataset leaving a total of 190 participants. For each of the 16 survey questions with missing data, the missing data were supplied by calculating the mean for that question and using that figure to complete the data set for that question. The mean was then recalculated for that question to verify that the supplied data did not change the mean. It was verified through statistical analysis that these new data did not change the mean for each question. For several variables, the categories were created or collapsed to fit the data collected. For example, additional categories were created for subject area taught as teachers reported teaching more than one subject. The results of this study address the following research questions:

1) What are general education teachers' attitudes toward the inclusion of students with special needs in the general education classroom as measured by the TATIP? 2) What are the relationships between teacher attitude scores and selected school and teacher variables (school setting, school performance level, grade and subject taught, years of experience, pre-service and inservice training and dual certification in special education)?

The demographic questionnaire was analyzed for the characteristics of the survey participants, the grades and subjects they teach, and the school variables addressed in this study. The number of teachers and percentages for each category appear in Table 3. Nonresponses were also included. It was necessary to include eight categories for the subject 
area taught as many middle school teachers and some high school teachers in smaller districts may teach more than one content area. Teachers classified as "other" may teach related arts classes or vocational classes.

TABLE 3

Demographic Data for Study Participants

Variable Number (percent)

Gender

Female

Male

No response

Age $\quad 21-30$

$31-40$

$41-50$

$51-60$

$61-70$

Mean Age

Years Teaching Experience

$1-5$ years

$6-20$ years

21 or more years

No response

Mean

Grade Level Taught

Middle School

High School
$129(68 \%)$

$59(31 \%)$

$2(1 \%)$

$38(20 \%)$

$46(24 \%)$

$51(27 \%)$

$48(25 \%)$

$7(4 \%)$

37

$50(26 \%)$

$93(49 \%)$

$45(24 \%)$

$2(1 \%)$

10.8

$117(62 \%)$

$59(31 \%)$ 
No response

$14(7 \%)$

Subject Taught

Mathematics

$35(18 \%)$

Science

$20(11 \%)$

Language Arts

$38(20 \%)$

Social Studies

$25(13 \%)$

Other

$31(16 \%)$

Mathematics/Science

$4(2 \%)$

Middle School all Subjects

$25(13 \%)$

Language Arts/Social Studies

$3(2 \%)$

No Response

$9(5 \%)$

School Setting

Urban

$107(56 \%)$

Suburban

$54(28 \%)$

Rural

$24(13 \%)$

No response

$5(3 \%)$

Training in Special Education

At Least One College Course

$112(59 \%)^{*}$

At Least One Inservice Training

$97(51 \%)^{*}$

Dual certification

$26(14 \%)$

School Performance Level (NCLB)

Meets Objective

$54(28 \%)$

Shows Progress

$68(36 \%)$

Identified for Improvement

$63(33 \%)$

No Response

$5(3 \%)$

*Equals more than $100 \%$ as some teachers had both college coursework and inservice training 
Table 4

Mean Numbers by Survey Questions

Variables

1. To teach students with LD or MMD is too hard a task to be handled by general education teachers.

2. The needs of the majority of children with disabilities can be met in the general classroom.

3. General classroom teachers cannot meet the academic needs of students with mild handicaps currently in their classrooms.

4. The social and emotional needs of children with mild disabilities are better met in resource classrooms than in general education classrooms.

5. Having a special education student in my classroom is disruptive.

6. Achievement levels of students with mild disabilities would increase if they were placed full time in the general education class.

7. Special education students should be served primarily through resource classes rather than in gen. ed. classes.

8. General education classroom teachers have the instructional skills to teach both students with mild handicaps and general education students.

\section{$\mathrm{N}$}

Mean

SD

Range

190

3.46

1.625

5

190

3.43

1.621

5

190

3.10

1.446

5

190

3.45

1.618

5

190

2.57

1.437

5

190

3.56

1.427

5

190

3.33

1.502

5

$190 \quad 3.46$

1.471

5 
9. To teach disruptive students is too

190

3.60

1.687

5 hard a task to be handled by general education teachers.

10. Everyone benefits from heterogeneous educational practices.

11. The general education teacher is required to make appropriate modifications in their teaching whenever a special education student's learning deficits influence their classroom success.

12. It is possible to adapt curriculum $190 \quad 4.55$ for a student with LD or MMD and/or a disruptive student.

13. Students with "normal curricula" 190 4.08 and students with "alternative curricula" can be taught in the same classroom.

14. Educational modifications that work with students with LD and different from those that work with average students.

15. General educators and special $190 \quad 5.18$ educators are coequal partners who share responsibility for the education of all children in their school.

16. In general, mainstreaming is a

To execute the analysis of the data for Research Question 1, the mean teacher attitude score was first calculated for the TATIP. The overall mean score for teacher attitudes toward inclusion was 3.79 with scores ranging from a low score of 2.96 and a 
high of 4.94 out of a possible score of 6.00 . Table 4 shows the mean and standard deviation for each question of the TATIP.

Results of the analysis of the data are discussed by the variable being studied. For each variable, correlation coefficients were computed to determine whether a significant relationship exists between teacher attitudes toward inclusion and the variables being investigated and the direction of that relationship. The Pearson Correlation Coefficient for each variable is listed in Table 5. Column 8 reveals a significant negative correlation

Table 5

Intercorrelations between Teacher Attitudes and Teacher and School variables $(\mathrm{n}=190)$ Subscale 1

1. Experience $1.00-.009$ 3 \begin{tabular}{llllll}
4 & 5 & 6 & 7 & 8 \\
\hline
\end{tabular}

2. Subject Area 1.0

3. Grade 1.00 $-.074$ $-.298^{* *}$ $.294^{* *} \quad .154 \quad-.164^{*}$

4. School $\begin{array}{lllll}1.00 & .220^{* *} & -.053 & .038 & .029\end{array}$ Setting

5. School $\begin{array}{llll}1.00 & -.077 & -.050 & -.035\end{array}$ Performance

6. College Courses $1.00 \quad .242 * * \quad-.015$

7. Inservice $1.00 \quad-.072$ Training

8. Teacher 1.00 Attitude ${ }^{*} p<.05,{ }^{* *} p<.01$. 
between teacher attitudes toward inclusion and the grade level taught $(r=-.164)$.

Significant relationships were also found between a number of teacher and school variables but these relationships are outside the focus of this study. An analysis of variance (ANOVA) was then executed to determine whether differences exist between groups within each variable. When significant differences were detected, a Tukey's post hoc test was run to identify where those differences exist. Table 6 contains the results of the ANOVA. The table shows a significant ANOVA in teacher attitudes toward inclusion for the grade level and subject area taught. Table 7 provides a summary of all findings.

When examining the effect of school setting on teacher attitudes toward inclusion, an ANOVA revealed no statistical significance. An examination of the mean scores showed that while the differences were not significant, teachers in suburban schools

Table 6

Analysis of Variance for Teacher and School Variables

\begin{tabular}{lccccc} 
Source & SS & df & MS & F & p \\
\hline Experience & .217 & 2 & .109 & .824 & .440 \\
Subject Area & 2.055 & 7 & .294 & $2.344^{*}$ & .026 \\
Grade Level & .203 & 2 & .102 & $6.66^{*}$ & .003 \\
School Setting & .225 & 2 & .113 & .460 & .635 \\
School Performance & .039 & 2 & .019 & .485 & .620 \\
College Courses & .005 & 1 & .005 & .040 & .841 \\
Inservice Training & .046 & 1 & .046 & .351 & .554 \\
error & 36 & & & & \\
\hline
\end{tabular}

$* \mathrm{p}<.05, * * \mathrm{p}<.01$ 
reported the most positive attitudes $(M=3.83)$ with those in rural schools reporting the most negative $(M=3.71)$. The widest range of attitude scores was found for teachers in urban schools ranging from 2.56 to 4.94 . A correlational analysis was run to determine if a relationship existed between school district as a subset of school setting, and teacher attitudes toward inclusion. A significant correlation was found: $\mathrm{r}(182)=.156, \mathrm{p}=.036$.

\section{Table 7}

Summary of Research Findings

Variable Correlation

ANOVA

School Setting .03 .46

School performance

$-.035$

College Courses Taken

$-.015$

.04

Inservice Traininng

$-.07$

Subject Area Taught

Grade Level Taught

$-.16^{*}$

$6.66^{*}$

Experience .04 .82 ${ }^{*} \mathrm{p}<.05$

When an ANOVA was performed though, no significance was found. A profile of the three districts including school setting and mean scores are listed in table 8.

An ANOVA revealed no significant differences when examining the relationship between teacher attitudes toward inclusion and school performance level. A correlational analysis yielded no significant relationship between these same variables. 
Table 8

School Setting by District

\begin{tabular}{lrrrrr} 
District & $\mathrm{N}$ & mean & $\mathrm{n}=\operatorname{rural}(\mathrm{m})$ & $\mathrm{n}=\operatorname{suburban}(\mathrm{m})$ & $\mathrm{n}=\operatorname{urban}(\mathrm{m})$ \\
\hline SD 1 & 5 & 3.7 & $5(3.7)$ & & \\
SD 2 & 152 & 3.77 & $2(3.6)$ & $45(3.8)$ & $103(3.8)$ \\
SD 3 & 22 & 3.85 & $15(3.7)$ & $5(4.1)$ & $2(4.2)$ \\
Other & 3 & 4.3 & $1(3.7)$ & $2(4.6)$ & \\
Total & 179 & 3.78 & $23(3.8)$ & $52(3.8)$ & $105(3.8)$ \\
\hline
\end{tabular}

No significant correlation was found between teacher attitudes toward inclusion and whether or not teachers had completed college courses in special education or inservice training. To further investigate a relationship between training and attitudes toward inclusion, the attitude scores of the teachers with a dual certification in special education but who were teaching in the general education program were examined. Twenty-six GETs reported having dual certification in special education. For this group, no significant correlation or mean difference was found. The TATIP score of the teachers with a dual certification in special education were virtually the same $(m=3.78)$ as those without certification in special education. When looking at the mean scores by group, those with dual certification reported a mean TATIP score of 3.85 while those without reported a mean score of 3.77. No significance was found for the correlational analysis or ANOVA when examining teacher attitudes toward inclusion and participation in inservice training. 
The effect of current grade level taught on teacher attitude was not significant when an ANOVA was performed. An examination of the means revealed that while not significantly different, middle school teachers reported a slightly more positive mean attitude score of $3.82(n=111)$ while high school teachers reported a mean score of 3.76 $(\mathrm{n}=58)$. A significant negative correlation between grade level taught and teacher attitude was found: $r(169)=-.16, p=.03$. As the grade level increases, teacher attitudes become less positive.

To further examine the impact of grade level on attitudes toward inclusion, each variable was analyzed for middle school and high school separately. An ANOVA revealed no significant difference between these two groups for years of experience, subject area taught, pre-service or inservice training, school setting, or school performance level. Middle school teachers with 21 or more years of experience $(\mathrm{m}=3.9)$ reported slightly more positive attitudes toward inclusion than high school teachers $(\mathrm{m}=$ 3.75). Middle school teachers in suburban schools $(m=3.9)$ also reported slightly more positive attitudes toward inclusion than high school suburban teachers $(m=3.7)$.

The effect of the subject area taught on teacher attitudes toward inclusion was examined. An ANOVA revealed a significant difference in attitude based on the subject area taught, $F(7,173)=2.34, p=.026$. A follow-up test to determine where differences between subject areas exist, found a significant difference in attitude between math teachers $(\mathrm{M}=3.65, \mathrm{SD}=.363), \mathrm{p}=.042$ and those who teach both language arts and social studies $(\mathrm{M}=4.31, \mathrm{SD}=.216), \mathrm{p}=.042$. An examination of the means revealed a range of scores from 2.56 for a teacher listed in the "other" category to 4.94 for a social 
studies teacher. Math teachers as a group reported the lowest mean score for attitude (M $=3.65$ ) though closely followed by science teachers.

An examination of the effects of total years of teaching on teacher attitudes toward inclusion using an ANOVA revealed no significant effect. A correlational analysis showed no significant relationship between years of teaching and teacher attitude toward inclusion. An examination of the mean scores showed that while the differences were not significant, teachers who had taught 21 years or more reported the highest attitude score $(\mathrm{M}=3.84, \mathrm{SD}=.385)$ and those who had taught 6 to 20 years reported the lowest attitude scores $(M=3.75, \mathrm{SD}=.374)$.

A power analysis was conducted using the Case I: One-Tail Significance Test table (Shavelson, 1996). At an alpha level of .05 and a sample size of 190 , the power was found to be .70 with a small effect size of .15 . This means that there is a $70 \%$ chance of correctly identifying a relationship between the teacher and school variables and teacher attitude. This low power analysis increases the risk of a type II error.

\section{Summary}

The goal of this study was to measure the attitudes of general education teachers toward the inclusion of students with special needs in their classrooms. Middle and high school teachers were the focus of this study as this group has been underrepresented in the literature. The survey used was the Teacher Attitude toward Inclusive Practices scale (TATIP). This instrument was developed from existing attitude scales found in the literature. Items from these instruments were modified for this study as described in Chapter 3. This study also examined the relationship between teacher attitudes toward 
inclusion and teacher and school variables. A significant relationship was found between general education teachers' attitude toward inclusion and the subject they teach (only between those who teach mathematics and those who teach both Language Arts and Social Studies), the grade level they teach (with middle school more positive than high school), and the district in which they teach.

When examining the findings of this study, it was somewhat surprising that significance was not found for the impact of teacher training on teacher attitudes toward inclusion as this has been reported in a number of studies to have a significant impact on teacher attitudes (Avramidis \& Kalyva, 2007; Brownell and Pajares, 1999; Koutrouba, Vamvakari \& Steliou, 2006). In this study, years of experience also failed to yield a significant relationship to teacher attitudes toward inclusion. This too is contradictory to prior research (Avramiddis \& Kalyva, 2007; Jung, 2007; Lohrmann \& Bambara, 2006; Tschannen-Moran \& Hoy, 2007). The results from this study support the findings in previous research on grade level and subject area taught and differ from results of others. It is hoped that this study will provide some new insights that will be discussed in chapter five. 


\section{CHAPTER 5}

\section{DISCUSSION}

This chapter will discuss the findings of the current study of teacher attitudes toward inclusion, the variables that influence teacher attitudes toward inclusion, and compare the findings from this study to the results reported in the literature. The implications of the impact the identified teacher and school variables have on teacher attitudes toward inclusion will be discussed. The implications of the findings of this study as well as the limitations of the study will also be discussed.

\section{Problem Statement}

Research has shown that teacher attitudes toward inclusion shape their expectations for their students, influence the instructional strategies used and ultimately impact student achievement (Kagan, 1992; Vaughn \& Schumm, 1996). The research questions that guided this study were:

1) What are general education teachers' attitudes toward the inclusion of students with special needs in the general education classroom as measured by the TATIP?

2) Is there a correlation between these attitude scores and selected school and teacher variables (school setting, school performance level as measured by No Child Left Behind, grade and subject taught, inservice and pre-service training background as well as certification category)? 


\section{Review of Methodology}

This study evaluated the attitudes of teachers toward the inclusion of students with special needs (Ssp) and the impact of teacher and school variables on these attitudes. Participants included middle and high school general education teachers recruited from school districts in a midwestern state. Teacher attitudes were assessed using the Teacher Attitudes Toward Inclusive Practices (TATIP) scale which was created by the researcher from existing instruments. The impact of selected teacher and school variables on teacher attitudes were examined using information obtained from a demographic questionnaire. These variables included the teachers' years of experience, pre-service and inservice training in special education including (?) certification in special education, the grade level and subject area taught, the school setting (urban, suburban, rural), and the school performance level.

An electronic survey including the demographic questionnaire and the TATIP were sent to middle and high school general education teachers from three school districts who agreed to participate in the study. Two hundred and thirty three surveys were returned with 190 being included in the final analysis. The data collected from the study were then analyzed using SPSS. Descriptive statistics from the sample were calculated. A correlational analysis and an analysis of variance were executed to evaluate the relationship between attitudes and teacher and school variables. A power analysis was also run for this study.

\section{Discussion of the Results}

The conceptual framework for this study illustrates the relationship between teacher attitudes toward inclusion, instructional practices, and student achievement as 
well as the influence of teacher and school variables on attitudes toward inclusion (see figure 1). Existing research supports the link between attitudes toward inclusion, instructional practices, and student achievement (Smith, 2000; Woolfolk, Rosoff, \& Hoy, 1990), the link between attitude and the identified variables are the focus of this study. In this section, the results of the study are discussed in relation to each research question. The results of this study are also compared to those found in the existing research reviewed in chapter 2 as well as the limitations of the study and directions for future research.

\section{Research Question 1}

Why is it important to study the attitudes teachers hold toward the inclusion of Ssp? As illustrated in the conceptual framework and supported by the literature, teacher attitudes toward inclusion influence perceptions of students, the instructional strategies implemented in the classroom, persistence in working with Ssp and ultimately student performance. In particular, students identified as Ssp have been disproportionately, negatively impacted by these attitudes which exasperate their existing learning difficulties.

Research question 1 addresses the overall attitude of GETs toward inclusion as measured by the TATIP. The mean attitude score for the teachers in this study was 3.79 on a scale of 1 to 6 with 1 representing the most negative response and 6 the most positive response. With a score of 3.5 representing a neutral attitude, the participants in this study reported an overall slightly positive attitude toward inclusion. The data revealed that $57 \%$ of the participating GETs reported an attitude score of 3.79 (the mean 
score) or lower reflecting neutral to negative attitudes toward inclusion. This may be compared to the findings of Scruggs and Mastropieri (1996) where approximately $60 \%$ of GETs held negative attitudes toward inclusion. Even though we have seen an increase in the number of students placed in inclusive classrooms over the past 13 years overall teacher attitudes toward inclusion appear to have changed very little.

When investigating the relationship between teacher attitudes toward inclusion and instruction, Kavale and Forness (2000) found that while GETs cared about the success of their Ssp, their instruction was geared toward conformity not the individualization of instruction. When planning instruction based on student performance, the majority of teachers reported only re-teaching content when $50 \%$ or more of their students did not grasp the concepts being taught (Bulgren, et al., 2002). Teachers who have been trained to utilize varied research based instructional strategies to address the varied learners at their grade level and have practiced and implemented these strategies under the guidance of a mentor may be more likely to attempt multiple strategies with their students. Middle and high school teacher training programs often do not include this specific training in strategies found to be effective for Ssp focusing instead on content knowledge.

Teachers who hold more negative attitudes toward inclusion may also be more likely to have preconceived notions about a student's ability to learn based on their disability label. Koutrouba, Vamvakari, and Steliou (2006) reported a negative correlation between the severity of a student's disability and teachers' attitudes. Over $72 \%$ of the teachers in the study felt that the severity of a student's disability impacted their successful integration into the general education classroom. Scruggs and 
Mastropieri (1996) found that $71 \%$ of teachers supported the inclusion of students with learning disabilities but, only $28.9 \%$ supported the inclusion of students with emotional/behavioral disabilities. This stresses the need to examine teacher attitudes toward inclusion more closely and the factors that influence attitudes, the focus of the second research question.

\section{Research Question 2}

The purpose of the second research question was to investigate the impact of selected teacher and school variables on teacher attitudes toward inclusion. These variables include the school setting (urban, suburban, rural), school performance level, pre-service and inservice training, certification areas (particularly whether they hold dual certification in general and special education), the grade level and subject area taught, and years of experience. The results of this study are compared with findings in the literature.

\section{School Setting}

While several studies have investigated the instructional differences for Ssp by school setting, very little research exists on the relationship between school setting and teacher attitudes toward inclusion. Though not statistically significant, the rural teachers in this study reported the least positive attitude scores which is similar to the findings of Larrivee and Cook (1979) thirty years ago. It is possible in smaller and more rural communities, that fewer students may be labeled with a disability providing GETs with less exposure to Ssp or an opportunity to become comfortable with inclusive strategies. 
This more negative attitude may also be due to a lack of resources including inservice training in the most current research based strategies that might be available to larger districts but not more rural or smaller school districts. It is essential that each state's department of education insure that teachers in all school settings receive the resources and training current in the field, needed to meet the needs of their Ssp.

\section{School Performance}

A review of the literature found no existing studies that looked at the impact of school performance based on a national accountability system, on teacher attitudes toward inclusion. While no significant relationship was found in this study, this variable may warrant further study. It has been suggested, though little research exists, that the stress brought on by the pressures of accountability testing negatively impacts attitudes toward inclusion (Ellins \& Porter, 2005). For example, in this midwestern state, Ssp are included in the state mandated assessments which included a writing portfolio, separate assessments in each academic area, and an on-demand writing component. Both assessments require full participation of Ssp. Rewards and sanctions were tied to a school's performance on this assessment increasing the stress on teachers with a high percentage of Ssp in their classroom to push these students to perform at increasingly higher levels. While assessment is important in insuring that all students are exposed to the general education curriculum, the failure to consider the percentage of students with disabilities and the extent of these disabilities may have contributed to the negative attitudes toward inclusion. Due to political and financial decisions made during the course of this study, the future of the assessment program in this Midwestern state is 
being reassessed and revised. This may have had some impact on the stress felt by teachers.

\section{Training}

When examining the impact of training, the teachers in this study reported no significant relationship between attitudes toward inclusion and pre-service and inservice training in special education. These findings are contradictory to those of earlier studies (Avramidis \& Kalyva, 2007; Brownell \& Pajares, 1999; Stoler, 1992). This may have been due in part to the research instrument which addresses training issues indirectly with statements like "GETs have the instructional skills..." and "GETs cannot meet the academic needs...".. In this current study, $38 \%$ reported having taken no college courses, $44 \%$ reported taking no inservice training, and $23 \%$ reported having taken no training of any kind in special education. This means that almost one quarter of the teachers surveyed may be working with Ssp in their classrooms with no training what-so-ever and at best, $21.8 \%$ have taken one or more college course as their only training and $14.9 \%$ have attended at least one hour of inservice training. Of the 47 teachers with $0-5$ years of experience, those most recently out of college, 10 reported having no pre-service or inservice training. While these findings are disturbing, Koutrouba, Vamvakari, and Steliou (2006) found that a lack of training was seen as the primary contributor to GET's negative attitudes toward inclusion with over $64 \%$ of teachers having never attended training in special education methods.

More and more frequently, GETs are required to implement instructional strategies and make evaluative decisions about their Ssp that would be made by the SET 
if students were educated in resource or self-contained classrooms. Teacher training and attitudes toward inclusion may impact their ability to perform these tasks. The literature supports the importance of GETs' understanding of a student's disability and its impact on learning and that the more training and experience teachers have, the more comfortable they are with the practice of inclusion (Brownell \& Pajares, 1999; Criswell, Anderson, Slate \& Jones, 1993; Minke, Bear, Deemer, \& Griffin, 1996).

An understanding of the strategies to make Ssp successful in the classroom may also lead to more confidence and a greater acceptance of Ssp. They may be more willing to collaborate with their special education peers to learn new strategies. When armed with research based instructional strategies, teachers in more challenging school settings may be better equipped to meet the needs of their students.

It is imperative too that training in research based instructional strategies be included in the more content specific training of middle and high school teachers as this and other studies show a negative correlation between teacher attitude and grade level. This will be discussed in more detail in the implications section of this chapter.

\section{Grade Level}

This study revealed a negative correlation between teacher attitudes toward inclusion and the grade level taught. This study also found that the lowest attitude scores were reported by the high school teachers surveyed. Other researchers report similar findings that support the notion that the higher the grade level taught, the more negative the teacher's attitude toward inclusion (Bender, Vail, \& Scott, 1995; Larrivee \& Cook, 1979; Lopes, Monteiro, Sil, Rutherford \& Quinn, 2004). Middle and high school teachers 
typically spend only one hour a day with their students and have less time to get to know their students and their individual academic needs. This places added importance on training in special education.

The special considerations associated with inclusion at the middle and high school level also need to be addressed. These include scheduling concerns, more difficult course material with the introduction of abstract concepts, an increased dependence on reading material, heavier work load, decreased student-teacher contact, and added social pressure. Scheduling time to work with the special education resource or consulting teacher may also be difficult.

Subject Area

When examining the impact of subject area taught, the range of TATIP scores was 3.65 to 3.9 . The attitude toward inclusion score for mathematics teachers $(\mathrm{m}=3.65$, $\mathrm{n}=35$ ) was at the bottom of this range followed by related arts and vocational education teachers $(m=3.7, n=31)$. The subject area at the more positive end of this range was science $(m=3.9, n=20)$. While the participants who teach both language arts and social studies $(m=4.3)$ reported the most positive attitude score there were only three teachers in this category. These findings vary somewhat from those in the literature.

Several earlier studies identified science and mathematics teachers as holding the most negative attitudes toward inclusion (Avramidis, Bayliss, \& Burden, 2000; Ellins \& Porter, 2005). As has been suggested in the literature, the lower attitudes held by science and mathematics teachers may be due to more challenging content and be affected by prior learning which may be missing for many Ssp. Another study though, found the most 
negative attitudes for the teachers of elective courses (related arts, vocational education) especially when looking at students with EBD (Johnson \& Fullwood, 2006). The lower attitudes reported by related arts teachers may be due to the lack of support provided to these teachers by SETs (Johnson \& Fullwood).

Determining the impact of subject area taught in this study was difficult as a number of participants reported teaching multiple subjects. This is addressed further in the limitations section. Middle school teachers and those in smaller districts often teach more than one content area. But, the reporting of lower attitudes by mathematics teachers is in agreement with much of the literature. Ssp often have difficulty with the abstract concepts and unfamiliar vocabulary in mathematics and science. The multiple steps necessary to solve many higher level mathematics calculations may also pose problems for Ssp. While pre-service and inservice training did not have a significant impact on attitudes toward inclusion, if teachers receive training in specific instructional strategies for Ssp in relation to specific content areas, they may feel less frustration, experience greater success, and hold more positive attitudes toward inclusion.

\section{Years of Experience}

In this study, the years of teaching experience had no significant impact on teacher attitudes toward inclusion. The data did show that teachers who had taught 21 years or more reported the highest attitude scores and those who had taught 6 to 20 years reported the lowest attitude scores. These findings were somewhat similar to those of Parasuram (2006) who found that teachers reported the most positive attitudes toward inclusion after 1 to 5 years of teaching and 25 or more years of teaching. The most 
negative attitudes were expressed by teachers with 15 to 20 years of experience. The majority of studies reviewed though reported a positive relationship between teacher attitudes and years of experience (Avramiddis \& Kalyva, 2007; Jung, 2007; Lohrmann \& Bambara, 2006; Tschannen-Moran \& Hoy, 2007). It is unclear as to why significance was not found in this study. It may be due to the small sample size of the study.

\section{Discussion by Survey Questions}

To better understand the attitudes toward inclusion of the participants in this study, the responses to specific questions were more closely examined. In this study, $48.5 \%$ of the teachers surveyed strongly agreed or moderately agreed with the statement that inclusion is a desirable practice (question 16). This means that over half of the teachers surveyed held either neutral or negative attitudes toward inclusion. An even lower percentage $(44.7 \%)$ of teachers strongly or moderately agreed that everyone benefits from inclusive practices (question 10). When comparing these findings to studies described earlier, it appears little has changed over time. Gickling and Theobald (1975), over 30 years ago, found that almost $50 \%$ of the teachers in their study considered inclusion to be an imposition. Cornoldi, Terreni, Scruggs and Mastropieri (1998) found that only $40.5 \%$ of teachers in the United States supported inclusion. The findings from the current study vary little from those in the literature and show that large numbers of teachers still hold neutral or negative feelings toward inclusion. This is somewhat surprising considering the emphasis placed on inclusion by IDEA. The little change observed in teacher attitudes over the past decade stresses the need to examine the factors contributing to negative attitudes and how this trend might be reversed. 
DeSimone and Parmar (2006) in their study of the attitudes of middle school mathematics teachers found that $80.3 \%$ agreed or strongly agreed that Ssp should have the opportunity to learn mathematics along with their general education classmates. But, only $41.6 \%$ of the teachers felt that Ssp were best taught in inclusive classrooms. In the current study, $25.5 \%$ of the teachers strongly or moderately agreed that Ssp should be served in resource rooms (question 7). This means that a quarter of all teachers do not feel that Ssp belong in their classroom. It is possible that these teachers hold such negative attitudes toward inclusion because they lack the training in appropriate instructional strategies to feel competent in meeting the needs of their Ssp. This may result in the students not receiving the support that they need and inhibiting them from making academic gains.

Koutrouba, Vamvakari, and Steliou (2006) found that a lack of training was seen as the primary contributor to GET's negative attitudes toward inclusion with over $64 \%$ of teachers having never attended training in special education methods. In this current study, $38 \%$ reported having taken no college courses, $44 \%$ reported taking no inservice training, and $23 \%$ reported having taken no training in special education. This means that almost one quarter of the teachers surveyed may be working with Ssp in their classrooms with no training what-so-ever and at best, $21.8 \%$ have taken a minimum of one college course as their only training and $14.9 \%$ have attended at least one hour of inservice training. So, with this limited training, it may not be surprising that the attitudes of GETs are lower than would be hoped.

When looking at the teachers' view of their role in educating Ssp, $71 \%$ of the teachers in this study strongly or moderately agreed that it was their responsibility to 
make modifications in their teaching for Ssp (question 11). But only $46 \%$ strongly or moderately agreed that students with normal curricula and those with an alternate curricula could be taught in the same classroom (question 13) and only $32 \%$ strongly or moderately agreed that they had the necessary skills to teach general and special education students in the same classroom (question 8). Almost $70 \%$ of the teachers surveyed held a neutral or negative opinion of their ability to teach Ssp.

\section{Implications}

In this study, a significant relationship was found between teacher attitudes toward inclusion and the grade level and subject area taught. The argument could be made that both of these variables may be influenced by the training these teachers have received.

Changing teacher attitudes toward inclusion requires a deep conceptual change. Teachers must examine the origin of their feelings toward inclusion and challenge the validity of those feelings for this change to occur. Kagan (1992) stated that teacher beliefs are rarely changed by reading articles or studying educational research. Teachers' beliefs act as a filter for all new learning. New knowledge that is congruent with the teacher's beliefs may be incorporated into their instructional practices. New ideas that are inconsistent with the teachers' beliefs may be rejected (Kagan). To facilitate conceptual change, the deeply held beliefs that shape teacher attitudes toward inclusion must be exposed and their inconsistencies with the role as a teacher, discussed. This may require placing pre-service teachers with negative attitudes toward inclusion, with strong mentor teachers in inclusive classrooms that are successfully meeting the needs of students with 
special needs. These pre-service teachers may not believe that inclusion is a desirable practice until they have had the opportunity to experience the situation firsthand. Kagan goes on to say that all pre-service teaching experiences should be closely supervised to ensure the quality of the placement. Students must be given the opportunity to examine and incorporate new learning into their belief system while being forced to examine their pre-existing beliefs.

Research seems to suggest that teachers learn most through practice and observing other teachers. Kagan (1992) suggested several instructional techniques involving personal reflection, which have been found to be effective in pushing both preservice and inservice teachers to examine their personal beliefs about teaching. The researcher encouraged the use of self reflection through the use of journals and video tapes which may be evaluated by a group of peers requiring the individual to evaluate /their beliefs from the perspective of other individuals (Kagan). Reviewing video tapes with a special education teacher may provide the GET with insight into more effective instructional strategies.

Brownell and Pajares (1999) found that the greater the number of special education courses taken by GETs, the more positive their perceptions of inclusive education. In an evaluation of teacher education programs though, Villa, Thousand, and Chapple (1996) stated that most university programs continue to follow distinct, categorical divisions in their teacher preparation. They state that too many programs fail to prepare their students to teach in a heterogeneous environment to children with a wide range of abilities. 
When examining the training programs for middle and high school teachers it is not surprising that a negative relationship exists between grade level taught and teacher attitudes toward inclusion. The pre-service training programs for middle and high school teachers focus primarily on content knowledge and general teaching methods. The college or university general methods instructors may be encouraged to incorporate special education instructional strategies into their instruction but it is not required. For example, at this university, certification in special education is a specialty area of certification tied to all elementary education programs. As with many university programs, teacher candidates in the general education programs are required to take one course in special education. Arthaud, Aram, Breck, Doelling and Bushrow (2007) assert that this may not be sufficient as most novice GETs fail to grasp the importance of the role they are expected to play in the education of Ssp.

Brownell \& Pajares, 1999 recommend that special education coursework and experiences be integrated into all regular education programs. This could occur in a number of ways. All pre-service GETs could be required to take special education courses addressing disability categories, legal issues and instructional strategies for high incidence disabilities. All field experiences could include some time in an inclusive classroom.

An alternative model for pre-service training might involve collaboration between the general education university faculty and faculty in special education. This model would allow pre-service teachers to learn and practice alternate instructional strategies in the context of each content area. Special education instructional strategies need to be incorporated into every class and activity. Field placements rich in inclusive opportunities 
are also essential but, these placements need to be closely monitored by university faculty.

As important as pre-service training is the ongoing training for GETs already working in inclusive classrooms. The current study found that the teachers with $6-20$ and those with 21 or more years experience $(n=92)$ and inservice training reported attitude scores of 3.9 versus 3.7 for those with no training. When asked about inservice training, Brownell and Pajares (1999) reported that teachers were most interested in training that addressed 1) needs of Ssp, 2) adaptations in curriculum and instruction, and 3) behavior management strategies. A mentoring program between GETs found to effectively include Ssp in their classes and those struggling to implement inclusion could be used to provide the hands-on experience needed. This training along with pre-service coursework in special education may encourage collaboration between GETs and SETs and thereby improve GETs attitudes toward inclusion (Brownell and Pajares).

Bulgren et al. (2002) surveyed 70 high school teachers about the modifications they currently used in the classroom for their Ssp. Of those surveyed, 33\% had no coursework in teaching Ssp and 61.5\% reported a desire for more professional development in effective instructional strategies for inclusion. Thirty-seven percent of the GETs reported modifying assignments by extending time, altering content and test formats, $12 \%$ modified teacher-student interactions to include one-on-one and small group instruction, and $4.5 \%$ reported using supplementary materials. Each teacher was also asked to list five research based instructional practices for a total of 350 possible responses. The teachers were able to generate only 150 total responses reflecting their limited knowledge of research supported instructional methods. Of the research based 
instructional practices identified, $17 \%$ of the teachers listed cooperative learning, $8.7 \%$ named group discussion or activities, $8 \%$ named direct instruction, and $4 \%$ named graphic organizers.

When discussing the importance of training GETs to use effective instructional strategies with their Ssp, it is also essential that SETs have the content knowledge necessary to support student learning. Both general education and special education training programs must ensure that all teachers have the knowledge they need to make all students successful.

\section{Limitations}

There are several limitations to this study that must be considered when evaluating the generalizability of the findings. As with all self-report surveys, the reliability of the data relies on the honesty of the respondents. Insuring that there are no obvious identifiers in the demographic questionnaire may encourage responses that truly reflect the teachers' attitudes toward inclusion, but cannot guarantee honest responses. This may also be confounded by the pressure of political correctness. It may not be considered politically correct to say that you do not want students with disabilities in your classroom.

Another limitation to this study is the sample size. While the response rate is considered acceptable for an internet survey, the small sample size limits the generalizability of the results and reduces the power of the study. Since the power analysis revealed a small effect size there is an increased risk of a type II error. An increased response rate could be achieved by introducing the study at the beginning of the 
school year, by contacting school administrators in person to explain the study, or by attending school staff meetings where teachers can complete the survey immediately. There also may be confounding numbers in the total sample size as the principals distributed the survey to people who were not eligible by the sample criteria. This might actually make the actual return rate higher.

The definition of key terms on the survey instrument was a limitation of this study. The vocabulary used in special education is constantly changing including such words as mainstreaming and inclusion. The survey instrument also referred to students with mild disabilities in several questions rather than the disability labels described in the preamble. The survey instrument was a composite of items from other instruments and that may have contributed to the confusion with the varied terminology. If the TATIP is used in future research, it would require some clarification and collapsing of terminology. A larger pilot study with the original 43 updated questions may have increased effect size and reliability. The power analysis for this study yielded only a $70 \%$ chance that significance was detected if it exists. This also means that relationships which were found not significant may have indeed been significant with a higher power analysis.

An examination of how some of the variables are defined may also be required. While NCLB was used as a standard measure of school performance level, other assessments of school performance may be more appropriate. The description of school setting relied on teacher report. A standard definition of urban, suburban and rural settings may have provided more accurate information. Also, assessing the impact of subject area taught was difficult as middle school teachers and some high school teachers teach more than one content area. This required the researcher to create categories of 
multiple subjects taught for the statistical analysis (ie. math, science, math and science) and complicated identifying specifically which content area was impacting attitude.

Lastly, a more thorough analysis of the data may provide more insight into the attitudes of GETs toward inclusion and the variables under investigation. This analysis might include a closer examination of the relationship between variables and their combined effect on attitudes toward inclusion. The data collected from the demographic questionnaire would also make it possible to look at the experience the participating teachers have had with students with different disabilities and how this experience impacts attitude. A second factor analysis of the survey items could also be run and the findings compared to the initial analysis run on the pilot sample.

All the limitations described above require a close examination of the threats to the validity of this study. The first is the low statistical power (.70) of the study which is more than likely the result of low sample size and the unreliability of the survey instrument. The weaknesses in the TATIP have already been discussed.

\section{Future Research}

When evaluating the results of this study, there are several aspects of the design that should be addressed. First, a larger sample size would improve the power of the study. This could be addressed by recruiting participants at the beginning of the school year rather than in the middle. In-person visits to each district to discuss the study might also improve the return rate. Secondly, further work needs to be done on the TATIP. A close evaluation of the questions used and further pilot tests conducted. Providing a qualitative component through classroom observations would make it possible to better 
assess the impact of attitude on the instructional strategies used and classroom climate. As with any survey study, the reliability of the data is dependent on the honesty of the participants. This concern could be addressed by comparing the survey data to the classroom observations.

A component of teacher attitude toward inclusion frequently addressed in the literature is teacher efficacy. The relationship between attitude and efficacy is not clearly defined though. This might be investigated by administering the TATIP as well as an efficacy scale to the same sample of teachers to explore the relationship between these two concepts.

Further research is also needed to better understand the role of grade level and subject area taught. While studies consistently show that the higher the grade level taught, the more negative the attitude toward inclusion, the causes for these negative attitudes need further study. The findings on the impact of subject area have been less consistent. This may require investigating the attitudes of teachers of each content area separately to identify the factors specific to each subject area that impact attitude.

While this study was designed to investigate the attitudes of middle and high school teachers, it would be interesting to conduct the same study using the TATIP to assess the attitudes of elementary teachers. The results using this instrument could then be compared to findings in the literature.

The relationship between teacher attitudes, the factors that influence attitudes, their possible impact on instruction and finally, student achievement justify the need for further investigation. 


\section{REFERENCES}

Abt Associates. (March, 2005). How well prepared are teachers to educate students with disabilities? Facts and Figures on Special Education. Retrieved on October 22, 2006 at www. abt.sliidea.org/Reports/Teacher\%20Preparation final2.pdf

American Heritage Dictionary, second college edition (1985). Houghton Mifflin Company, Boston, MA.

Antonak, R. F., \& Livneh, H. (1988). The measurement of attitudes toward people with disabilities; Methods, psychometrics, and scales. Springfield, IL. Thomas.

Arthaud, T. J., Aram, R. J., Breck, S. E., Doelling, J. E., \& Bushrow, K. M. (2007). Developing collaboration skills in pre-service teachers: A partnership between general and special education. Teacher Education and Special Education, 30, 1 12.

Avramidis, E., Bayliss, P., \& Burden, R. (2000). Student teachers' attitudes towards the inclusion of children with special educational needs in the ordinary school. Teaching and Teacher Education, 16, 277-293.

Avramidis, E., \& Kalyva, E. (2007). The influence of teaching experience and professional development on Greek teachers' attitudes towards inclusion. European Journal of Special Needs Education, 22, 367-389.

Bandura, A. (1993). Perceived self-efficacy in cognitive development and functioning. Educational Psychologist, 28, 117-148.

Bandura, A. (1986). Social foundations of thought and action: A social cognitive theory. Englewood Cliffs, NJ: Prentice-Hall.

Bender, W. N. (1985). The case against mainstreaming: Empirical support for the political backlash. Education, 105, 279-287.

Bender, W. N., \& Ukeje, I. C. (1989). Instructional strategies in mainstream classrooms: Prediction of the strategies teachers select. Remedial and Special Education, 10, 23-30. 
Bender, W. N., Vail, C. O., \& Scott, K. (1995). Teachers' attitudes toward increased mainstreaming: Implementing effective instruction for students with learning disabilities. Journal of Learning Disabilities, 28, 87-94.

Brookover, W. B., Schweitzer, J. H., Schneider, J. M., Beady, C. H., Flood, P. K., \& Wisenbaker, J. M. (1978). Elementary school social climate and school achievement. American Educational Research Journal, 15, 301-318.

Brownell,M. T., \& Pajares, F. (1999). Teacher efficacy and perceived success in mainstreaming students with learning and behavior problems. Teacher Education and Special Education, 22, 154-164.

Buell, M. J., Hallam, R., Gamel-McCormick, M., \& Scheer, S. (1999). A survey of general and special education teachers' perceptions and inservice needs concerning inclusion. International Journal of Disability, Development and Education, 46, 143-156.

Bulgren, J. A., Lenz, B. K., McKnight, M., Davis, B., Grossen, B., Marquis, J., et al. (2002). The educational context and outcomes for high school students with disabilities: The perceptions of general education teachers (Research report). Kansas City, KS: Lawrence Institute for Academic Access.

Bureau of Exceptional Education and Student Services (2006, February). The response to intervention (RtI) model.

Chiang, L. H. (1999). Secondary teachers' perceptions of regular education initiative. Paper presented at the Mid- western Educational Research Conference, Chicago, IL.

Cook, B. G., Semmel, M. I., \& Gerber, M. M. (1999). Attitudes of principals and special education teachers toward the inclusion of students with mild disabilities. Remedial and Special Education, 20, 199-207.

Cook, B. G., Tankersley, M., Cook, L., \& Landrum, T. J. (2000). Teachers' attitudes toward their included students with disabilities. Exceptional children, 67, 115135 .

Cornoldi, C., Terreni, A., Scruggs, T. E., \& Mastropieri, M. A. (1998). Teacher attitudes in Italy after twenty years of inclusion. Remedial and Special Education, 19, 350356.

Criswell, D., Anderson, R., Slate, J. R., \& Jones, C. H. (1993). Attitudes of school personnel toward special education as a function of position, years of experience, and contact with students with disabilities. Paper presented at the annual meeting of the Mid-South Educational Research Association, New Orleans, LA. 
DeSimone, J. R. \& Parmar, R. S. (2006). Middle school mathematics teachers' beliefs about inclusion of students with learning disabilities. Learning Disabilities Research \& Practice, 21, $98-110$.

Dunn, L. M. (1968). Special education for the mildly retarded-Is much of it justifiable? Exceptional Children, 35, 5-22.

Ellins, J. \& Porter, J. (2005). Departmental differences in attitudes to special educational needs in the secondary school. British Journal of Special Education, 32, 188-195.

Garrison, W. (2004). Profiles of classroom practices in U.S. public schools. School Effectiveness and School Improvement, 15, 377 - 406.

George, D., \& Mallery, P. (2003). SPSS for Windows Step by Step. Boston, MA: Allyn and Bacon.

Gibson, S., Dembo, M. H. (1984). Teacher efficacy: A construct validation. Journal of Educational Psychology, 76, 569-582.

Gickling, E. E., and Theobald, J. T. (1975). Mainstreaming: Affect or effect. The Journal. of Special Education, 9, 317-328

Hughes, J. N., Cavell, T. A., \& Willson, V. (2001). Further support for the developmental significance of the teacher-student relationship. Journal of School Psychology, 39, 289-301.

Hughes, J. N., Gleason, K. A., \& Zhang, D. (2005). Relationship influences on teachers' perceptions of academic competence in academically at-risk minority and majority first grade students. Journal of School Psychology, 43, 303-320.

Instructional Assessment Resources (2007). Response rates. Retrieved February 9, 2009 from http://www.utexas.edu/academic/diia/assessment/iar/teaching/gather/ method/survey-Response.php

Johnson, H. L. \& Fullwood, H. L. (2006). Disturbing behaviors in the secondary classroom: How do general educators perceive problem behaviors? Journal of Instructional Psychology, 33, 20-39.

Jung, W. S. (2007). Preservice teacher training for successful inclusion. Education, 128, 106-113.

Kagan, D. M. (1992). Implications of research on teacher belief. Educational Psychologist, 27, 65-90.

Kavale, K. A., \& Forness, S. R. (2000). History, rhetoric, and reality: Analysis of the inclusion debate. Remedial and Special Education, 21, 279-296. 
King, I. C. (2003). Examining middle school inclusion classrooms through the lens of learner-centered principles. Theory Into Practice, 42, 151-158.

Knoblauch, D., \& Woolfolk Hoy, A. (2008). "Maybe I can teach those kids." The influence of contextual factors on student teachers' efficacy beliefs. Teaching and Teacher Education, 24, 166-179.

Kolb, K. J., \& Jussim, L. (1994). Teacher Expectations and underachieving gifted children. Roeper Review, 17, 26-30.

Koutrouba, K., Vamvakari, M., \& Steliou, M. (2006). Factors correlated with teachers' attitudes towards the inclusion of students with special educational needs in Cyprus. European Journal of Special Needs Education, 21, 381-394.

Kuklinski, M. R., \& Weinstein, R. (2001). Classroom and developmental differences in a path model of teacher expectancy effects. Child Development, 72, 1554-1578.

Larrivee, B., \& Cook, L. (1979). Mainstreaming: A study of the variables affecting teacher attitude. The Journal of Special Education, 13, 315-324.

Liljequist, L., \& Renk, K. (2007). The relationships among teachers' perceptions of student behaviour,teachers' characteristics, and ratings of students' emotional and behavioral problems. Educational Psychology, 27, 557-571.

Lohrmann, S., \& Bambara, L. M. (2006). Elementary education teachers' beliefs about essential supports needed to successfully include students with developmental disabilities who engage in challenging behaviors. Research and Practice for Persons with Severe Disabilities, 31, 157-173.

Lopes, J. A., Monteiro, I., Sil, V., Rutherford, R. B., \& Quinn, M. M. (2004). Teachers' perceptions about teaching problem students in regular classrooms. Education and Treatment of Children, 27, 394-419.

Madden, N. A. \& Slavin, R. E. (1983). Mainstreaming students with mild handicaps: Academic and social outcomes. Review of Educational Research, 53, 519-569.

Martinez, R. S., Nellis, L. M., \& Prendergast, K. A. (2006). Response to intervention (RTI) - Basic elements, practical applications, and policy recommendations. Center for Evaluation and Education Policy, 4, 1-6.

McLeskey, J., \& Pacchiano, D. (1994). Mainstreaming students with learning disabilities: Are we making progress? Exceptional Children, 60, 508-517. 
Minke, K. M., Bear, G. G., Deemer, S. A., \& Griffin, S. M. (1996). Teachers' experiences with inclusive classrooms: Implications for special education reform. The Journal of Special Education, 30, 152-186.

Munro, J. (1999). Learning more about learning improves teacher effectiveness. School Effectiveness and School Improvement, 10, 151-171.

National study on inclusion: Overview and summary report. (1995). National Center on Educational Restructuring and Inclusion Bulletin, 2, 3-10.

Nespor, J. (1987). The role of beliefs in the practice of teaching. Journal of Curriculum Studies, 19, 317-328.

Obiakor, F. E. (1999). Teacher expectations of minority exceptional learners: Impact on "accuracy" of self-concepts. Exceptional Children, 66, 39-53.

Pajares, M. F. (1996). Self-efficacy beliefs in academic settings. Review of Educational Research, 66, 543-578.

Pajares, M. F. (1992). Teachers' beliefs and educational research: Cleaning up a messy construct. Review of Educational Research, 62, 307-332.

Parasuram, K. (2006). Variables that affect teachers' attitudes towards disability and inclusive education in Mumbai, India. Disability and Society, 21, 231-242.

Ross, J. A., Cousins, J. B., \& Gadalla, T. (1996). With-in teacher predictorsof teacher efficacy. Teaching and Teacher Education, 12, 385 - 400.

Safran, S. P., Safran, J. S., \& Orlansky, M. D. (1982). The effects of prior information upon perceptions of exceptional children. Contemporary Educational Psychology, 7, 384-394.

Scruggs, T. E., \& Mastropieri, M. A. (1996). Teacher perceptions of mainstreaming/inclusion, 1958-1995: A research synthesis. Exceptional Children, $63,59-74$.

Semmel, M. I., Abernathy, T. V., Butera, G., \& Lesar, S. (1991). Teacher perceptions of the regular education initiative. Exceptional Children, 58, 9-15.

Shavelson, R. J. (1996). Statistical reasoning for the behavioral sciences. Boston, MA: Allyn and Bacon.

Siegel, J. (1992). Regular education teachers' attitudes toward their mainstreamed students. Paper presented at the annual Convention of the Council for Exceptional Children, Baltimore, MD. 
Siegel, J., \& Jausovec, N. (1994). Improving teachers' attitudes toward students with disabilities. Paper presented at the Conference of the International Council on Education for Teaching, Istanbul, Turkey.

Silberman, M. L. (1969). Behavioral expression of teachers' attitudes toward elementary school students. Journal of Educational Psychology, 60, 402-407.

Silva, J. C., \& Morgado, J. (2004). Support teachers' beliefs about the academic achievement of students with special educational needs. British Journal of Special Education, 31, 207-214.

Smith, M. G. (2000). Secondary teachers' perceptions toward inclusion of students with severe disabilities. National Association of Secondary School Principals. NASSP Bulletin, 84, 54-60.

Soodak, L. C., Podell, D. M., \& Lehman, L. R. (1998). Teacher, student, and school attributes as predictors of teachers' responses to inclusion. The Journal of Special Education, 31, 480-497.

Special education and the individuals with disabilities education act. NEA Today (n.d.). Retrieved October 22, 2006 www.nea.org/specialed/index.html

Stella, C. S., Forlin, C., \& Lan, A. M. (2007). The influence of an inclusive education course on attitude change of pre-service secondary teachers in Hong Kong. AsiaPacific Journal of Teacher Education, 35, 161-179.

Stoler, R. D. (1992). Perceptions of regular education teachers toward inclusion of all handicapped students in their classrooms. Clearing House, 66, 60-63.

Tschannen-Moran, M. \& Hoy, A. W. (2007). The differential antecedents of self-efficacy beliefs of novice and experienced teachers. Teaching and Teacher Education, 23, 944-956.

U.S. Department of Education (2005). $27^{\text {th }}$ annual report to Congress on the implementation of the individuals with disabilities education act. Washington, DC: U.S. Government Printing Office.

Vaughn, S.,\& Schumm, J. S. (1996). Classroom ecologies: Classroom interactions and implications for inclusion students with learning disabilities. In D. L. Speece \& B. K. Keogh (Eds.), Research on classroom ecologies: Implications for students with learning disabilities (pp. 107-124). Mahwah, NJ: Erlbaum.

Villa, R. A., Thousand, J. S., \& Chapple, J. W. (1996). Preparing teachers to support inclusion: Preservice and inservice programs. Theory Into Practice, 35, 42-50. 
Villa, R. A., Thousand, J. S., Meyers, H., \& Nevin, A. (1996). Teacher and administrator perceptions of heterogeneous education. Exceptional Children, 63, 29-45.

Voltz, D. L., Brazil, N., \& Ford, A. (2001). What matters most in inclusive education. Intervention in School and Clinic, 37, 23-30.

Watson, S. C. (1998). A primer in survey research. Journal of Continuing Higher Education, winter, 31-40.

Wilcox-Herzog, A., \& Ward, S. L. (2004). Measuring teachers' perceived interactions with children: A tool for assessing beliefs and intentions. Early Childhood Research and Practice, 6. Retrieved August 1, 2009, from http://ecrp.uiuc.edu/v6n2/herzog.html

Woolfolk, A., Rosoff, B., \& Hoy, W. K. (1990). Teachers' sense of efficacy and their beliefs about managing students. Teaching and Teacher Education, 6, 137-148. 
APPENDIX A

SURVEY PREAMBLE

This survey is being conducted as part of a dissertation study at the University of Louisville to evaluate the impact teachers and schools have on students with special needs (Ssp). It is hoped that the findings from this study may be used to guide pre-service and inservice training for general education teachers.

Middle and high school general education teachers are asked to complete a brief demographic sheet, and a 16 question survey. The questions in this survey should be considered general statements about your beliefs toward students with special needs and not specific to your current teaching position. For the purpose of this study, students with special needs refer only to those students with learning disabilities, emotional and behavior disorders, and mild mental disability. Inclusion may be defined as when students with special needs spend 80 percent or more of their instructional day in a general education classroom. The survey should take between 5 and 10 minutes to complete.

Participation in this study is voluntary. Should you choose to participate, your responses to this survey will be confidential. Teacher and school names will not be collected and district names will never be identified in the study.

Thank you in advance for your participation,

Karla Stauble 


\section{APPENDIX B: DEMOGRAPHIC SHEET}

Please take a few moments to complete the demographic information below. Please do not put your name on this form. The information on the Attitude Scale and the demographic sheet are anonymous.

School District:

Personal Information:

Age:

$$
21-30
$$
$31-40$

$41-50$ $51-60$

$$
61-70
$$
over 70

Gender: $\square$ Male $\square$ Female

Total years of teaching experience: less than 1 $1-4$ $5-8$

9-12 $13-16$ $17-20$ $21-24$ 25 or more

Current position/subject teaching

Areas of Certification you hold and years taught in each:

$\square$ Early Childhood Education yrs. (birth - age 4)

$\square$ Elementary Education yrs. $(K-5)$

$\square$ Middle Level Education $(6-8)$

$\square$ Secondary Level Education: $(9-12)$ $\square$ Special Education mathematics language arts mathematics language arts

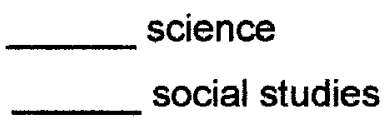

science social studies 


\section{Classroom Information:}

Approximately how many students identified with the following disorders have you taught in your career?

LD

EBD

MMD

Does a special education teacher: $\square$ team teach in your classroom

$\square$ Collaborate with you daily

$\square$ Provide an instructional assistant

Have you taken college classes in special education? If yes, how many?

$\square$ yes \# of classes

$\square$ no

Have you attended inservice training in special education? If yes, how many hours?

$\square$ yes \# of hours

ano

What category best describes the majority of students in your class:

$$
\square \text { rural } \square \text { suburban } \square \text { urban }
$$

How is your school classified under "No Child Left Behind"?
$\square$ meets objective
$\square$ shows progress
$\square$ identified for improvement 


\section{APPENDIX C}

This survey has been designed to measure your beliefs about students with mild disabilities in your classrooms and the training you've received to prepare you to teach students with special needs.

Directions: Please indicate by circling the appropriate number, the degree to which you agree or disagree with each of the following statements. Refer to the scale below.

\begin{tabular}{cccccc}
\hline & & & & & \\
1 & 2 & 3 & 4 & 5 & 6 \\
Strongly & Moderately & Slightly & Slightly & Moderately & Strongly \\
Disagree & Disagree & Disagree & Agree & Agree & Agree
\end{tabular}

1. To teach students with LD or MMD is too hard a task to be handled by general education teachers.

$\begin{array}{llllll}1 & 2 & 3 & 4 & 5 & 6\end{array}$

2. The needs of the majority of children with disabilities can be met in the general classroom.

3. General classroom teachers cannot meet the academic needs of students with mild handicaps currently in their classrooms.

4. The social and emotional needs of children with mild disabilities are better met in resource classrooms than in general education classrooms.

5. Having a special education student in my classroom is disruptive.

6. Achievement levels of students with mild disabilities would increase if they were placed full time in the general education classroom.

7. Special education students should be served primarily through resource classes rather than in general ed classes.

$\begin{array}{llllll}1 & 2 & 3 & 4 & 5 & 6\end{array}$

$\begin{array}{llllll}1 & 2 & 3 & 4 & 5 & 6\end{array}$

$\begin{array}{llllll}1 & 2 & 3 & 4 & 5 & 6\end{array}$

$\begin{array}{llllll}1 & 2 & 3 & 4 & 5 & 6\end{array}$

$\begin{array}{llllll}1 & 2 & 3 & 4 & 5 & 6\end{array}$

$\begin{array}{llllll}1 & 2 & 3 & 4 & 5 & 6\end{array}$ 


\begin{tabular}{cccccc}
\hline 1 & 2 & 3 & 4 & 5 & 6 \\
Strongly & Moderately & Slightly & Slightly & Moderately & Strongly \\
Disagree & Disagree & Disagree & Agree & Agree & Agree
\end{tabular}

8. General education classroom teachers have the instructional skills to teach both students with mild handicaps and general education students.

9. To teach disruptive students is too hard a task to be handled by general education teachers.

10. Everyone benefits from heterogeneous educational practices.

11. The general education teacher is required to make appropriate modifications in their teaching whenever a special education student's learning deficits influence their classroom success.

12. It is possible to adapt curriculum for a student with LD or MMD and/or a disruptive student.

13. Students with "normal curricula" and students with "alternative curricula" can be taught in the same classroom.

14. Educational modifications that work with students with learning disabilities are different from those that work with average students.

15. General educators and special educators are coequal partners who share responsibility for the education of all children in their school.

16. In general, mainstreaming is a desirable educational practice.

$\begin{array}{llllll}1 & 2 & 3 & 4 & 5 & 6\end{array}$ 6 


\section{APPENDIX D}

The following IRB Protocol has been marked as Exempt.

Tracking \#: 08.0521

PI: Lingo, Amy

Title: Teacher and School Variables that Impact Attitudes Toward Inclusion The following IRB Protocol has been marked as Exempt.

Link to BRAAN2 Login Help is available at the BRAAN2 Help Site For additional assistance please call the Human Subjects Protection Program at 502-8525188. 


\section{CURRICULUM VITAE}

\section{Karla R. Stauble}

University of Louisville

College of Education and Human Development

Department of Teaching and Learning, Rm. 266

Louisville, KY 40292

4020 Sweeney Lane

Louisville, KY 40299

Phone: (502) 267-5930

Email: krstau01@louisville.edu

\section{EDUCATION}

2009 Ph,D, Program, Curriculum and Instruction; Special Education, Department of Teaching and Learning, University of Louisville Expected completion date: July 22, 2009

1996 M. Ed., Special Education, University of Louisville

1981 B.S., Animal Science, College of Agriculture, University of Kentucky

\section{PROFESSIONAL AND WORK EXPERIENCE}

Spring 2009

Fall 2008

Summer 2008

Spring 2008

Fall 2007

Spring 2007

2005- 2009
Adjunct Instructor, EDSP 337: Collaboration, Inclusion, and Transition, University of Louisville

Adjunct Instructor, EDSP 441: Methods for Students with Learning and Behavior Disorders and

EDSP 442: Special Education Practicum, University of Louisville

Adjunct Instructor, EDSP 545: Exceptional Children in the Regular classroom, University of Louisville

University Supervisor for Special Education Student Teachers University of Louisville

Adjunct Instructor, EDSP 442: Special Education Practicum University of Louisville

Adjunct Instructor, EDSP 596: Seminar in Special Education University of Louisville

Graduate Research Assistant, University of Louisville, Department of Teaching and Learning 
Responsibilities:

- Member of the CEHD diversity study research team

- Assisting with the evaluation of Reading Mastery and Great Leaps literacy programs for at-risk middle school students (with Dr. Amy Lingo)

- Primary observer for an early childhood behavior intervention plan using a single-subject research design observing students referred for antisocial behaviors, coordinated observations with secondary observer, attended study planning meetings, obtained consent from parents and teachers in the study, maintained observation records (with Dr. Amy Lingo, Dr. Peter Alter, and Dr. Andy Frey)

- Assisted in the implementation of a Summer Science Institute for at-risk middle school students as part of a three-year grant to enhance student awareness of science in the community and science careers, maintained student records, compiled data, assisted professors as needed and prepared the Results and Conclusions section of study write-up (with Dr. Sherri Brown and Dr. Thomas Tretter)

$1996-2003$

Special Education Teacher, resource/collaborative setting J. Graham Brown School, Jefferson County Public Schools, Louisville, KY

1993 - 1996 Special Education Teacher, Emotional Behavior Disorder selfcontained classroom

Noe Middle School, Jefferson County Public Schools, Louisville, KY

1987 - $1991 \quad$ Educator, Louisville Zoological Gardens

1982 - 1987 Dietician, Louisville Zoological Gardens

\section{CERTIFICATIONS}

High School Biology

K-12 Special Education, Learning and Behavior Disorders

\section{MANUSCRIPTS IN PROGRESS}

Stauble, K. R., Gianelloni, M. (2009). The impact of a week-long science program at the zoo on student knowledge of and attitude toward science.

Manuscript in progress.

Brown, S. L., Tretter, T. R., Stauble, K. R., \& Votaw, N. (2009). Impact of a summer science institute on urban middle school students' perceptions of science. Manuscript in progress.

Frey, A, Lingo, A., Alter, P., \& Stauble, K. R. (2009). The impact of an early childhood behavior intervention plan on disengagement and antisocial behaviors. Manuscript in progress. 


\section{REFEREED PRESENTATIONS}

Stauble, K. R. (2009, January). The impact of a week-long science program at the zoo on student knowledge of and attitude toward science. Poster presentation at the Association for Science Teacher Education conference, Hartford, CT.

Frey, A., Lingo, A., Alter, P., \& Stauble, K. R. (2007, April). The impact of an early childhood behavior intervention plan on disengagement and antisocial behaviors. Paper to be presented at the Council for Exceptional Children regional conference, Louisville, KY.

Brown, S. L., Tretter, T. R., Stauble, K. R., \& Votaw, N. (2007, January). Impact of a summer science institute on urban middle school students' perceptions of science. Paper presented at the Association for Science Teacher Education conference, Clearwater, FL.

Lingo, A., Bronger, T., \& Stauble, K. R. (2006, November). Addressing challenges in preparing highly qualified special education teachers through alternative certification. Paper presented at the Teacher Education Division (TEDS) of the Council for Exceptional Children conference, San Diego, CA.

\section{PROFESSIONAL SERVICE ACTIVITIES}

2007

$2005-2007$

Spring 2006

Spring 2006

$2006-2007$

2000
Kappa Delta Pi Honor Society, Vice President

Student representative, Curriculum Committee, University of Louisville Co-instructor, EDSP 300 (with Dr. Amy Lingo)

Member of the Spring Research Conference Committee, University of Louisville Participant, Future Faculty Program, University of Louisville Special Education committee member, "Curriculum Guide for New Teachers" (writing team for high school biology) for Jefferson County Public Schools

\section{GRANTWRITING EXPERIENCE}

2006

Graduate Research Assistant "Mathematical Interventions for Students with Disabilities. "Dr. Amy Lingo and Dr. Todd Brown, Co-PIs. Submitted: February, 2006. Status: Unfunded.

Duties: Conducted literature search and performed statistical analysis

\section{COMMUNITY INVOLVEMENT}

2005 - present $\quad$ Co-founder of The Jamie and Cory Foundation, Louisville $\mathrm{KY}_{3}$ Duties: Evaluating grant and scholarship applications for a $\$ 4$ - 
million private foundation which annually awards six $\$ 20,000$ scholarships and over $\$ 150,000$ in grants; monitoring foundation investments; creating and updating foundation documents/forms; daily operational oversight

2005 - present Member of the Louisville Donor's Forum, Louisville, KY Duties: As a voting member, responsible for attending quarterly meetings concerning state and federal laws affecting nonprofit organizations

\section{MEMBERSHIP IN PROFESSIONAL ASSOCIATIONS}

Association for Science Teacher Education

Council for Exceptional Children

American Educational Research Association

\section{HONORS}

Kappa Delta Pi Honor Society

\section{RESEARCH INTERESTS}

- The Impact of teacher and school variables on teacher attitudes toward inclusion (dissertation study)

- Over representation of minorities in high incidence special education categories

- Identification of effective teaching strategies in math and science for middle and high school students with special needs

- Early intervention strategies for preschool students identified as having antisocial behaviors 